\title{
Stratigraphy and Structure of
}

the House Rock Valley Area Coconino County, Arizona

3y JOHN D. WELLS

CONTRIBUTIONS TO GENERAL GEOLOGY

G O L O G I A L S UR V E Y B U L L E T I N $1081-\mathrm{D}$

Prepared on behalf of the U.S. Atomic Energy Commission and published with he permission of the Commission

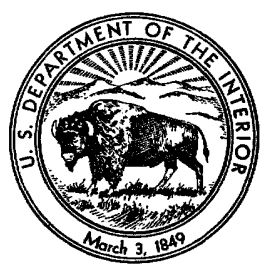




\title{
UNITED STATES DEPARTMENT OF THE INTERIOR
}

FRED A. SEATON, Secretary

\author{
GEOLOGICAL SURVEY
}

Thomas B. Nolan, Director 


\section{CONTENTS}

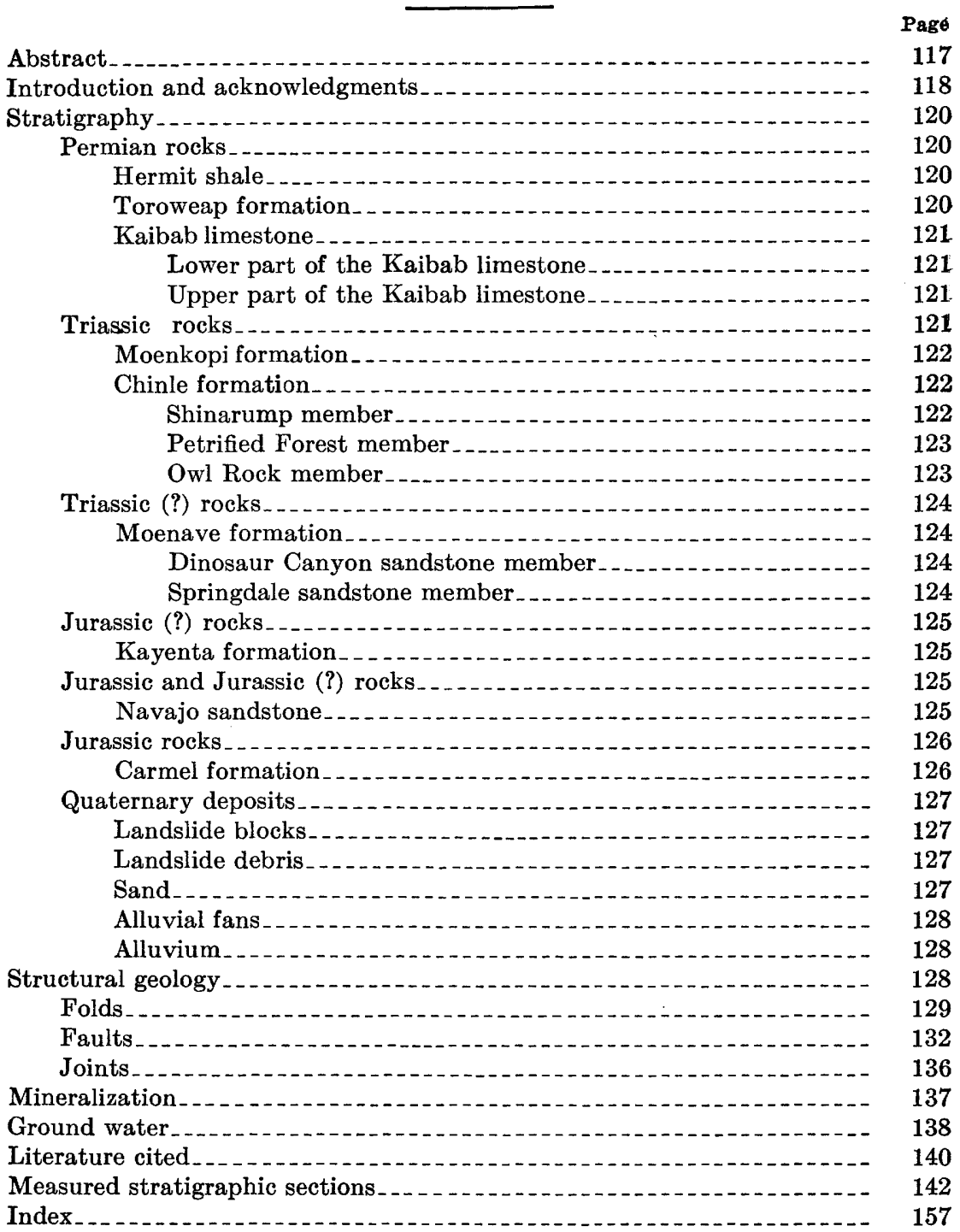

\section{ILLUSTRATIONS}

[Plates are in pocket]

Plate 4. Geologic map of the House Rock Valley area.

5. Tectonic map of the House Rock Valley area.

Figure 11. Index map showing location of the House Rock Valley area.-

12. Graphic plots of fold axes, faults, and joints. 



\title{
CONTRIBUTIONS TO GENERAL GEOLOGY
}

\section{STRATIGRAPHY AND STRUGTURE OF THE HOUSE ROGK VALLEY AREA, GOCONINO COUNTY, ARIZONA}

\author{
By JoHn D. WeuLS
}

\begin{abstract}
The House Rock Valley area consists of four $7 \frac{1}{2}$-minute quadrangles : House Rock Spring NE, House Rock Spring SE, Paria Plateau NW, and Paria Plateau SW. These quadrangles cover House Rock Valley, part of the Paria Plateau, part of the East Kaibab monocline, and part of the Kaibab Plateau.

The bedrock in the area consists of: (a) Red siltstone in the Hermit shale, gypsum in the Toroweap formation, and dolomite, limestone, and sandstone in the Toroweap formation and Kaibab limestone, all of Permian age; (b) red siltstone and sandstone in the Moenkopi and Chinle formations of Triassic age and in the Moenave formation of Triassic(?) age, gray and red mudstone in the Chinle formation, and conglomeratic sandstone in the Shinarump member of the Chinle formation; (c) red sandstone and siltstone in the Kayenta formation of Jurassic(?) age and in the Carmel formation of Jurassic age, red and white eolian sandstone in the Navajo sandstone of Jurassic and Jurassic(?) age, and red limestone in the Carmel formation. The Coconino sandstone is absent. The upper part of the Navajo sandstone and lower part of the Carmel formation are intertongued. In the Chinle formation the Shinarump member is thin in the northern part of the area and absent in the southern part; the Owl Rock member is thin or absent. All other units are typical of the rocks on the Colorado Plateau.
\end{abstract}

Surficial Quaternary deposits are landslide blocks, landslide debris, sand, alluvial fans, and alluvium.

The tectonic structures in this area-folds, faults, and joints-are typical of those on the Colorado Plateau. The most prominent feature is the East Kaibab monocline, a 130-mile-long arcuate fold, which has the west side upthrown 3,500 feet. Nearly parallel to the monocline are high-angle faults with offsets of several hundred feet; some have the east side upthrown, others have the west side upthrown. Many minor folds and faults trend nearly parallel to and diagonally to the monocline. Joints trend parallel to both the major and minor faults and folds. Some of the minor structures-shear zones and thrust faults-were formed by local compression while the high-angle faults, horsts, and grabens were formed by tension.

No ore deposits are known to exist in the area although abnormally high radioactivity and copper minerals are present.

Small amounts of water occur at the base of the Navajo sandstone and in the unconsolidated surficial deposits. 


\section{INTRODUCTION AND ACKNOWLEDGMENTS}

The House Rock Valley area is in Coconino County, Ariz., about 20 miles west of Lees Ferry and 10 miles northeast of the lodge at Jacob Lake (fig. 11). The north boundary is essentially the Arizona-Utah State line. The area includes four $7 \frac{1}{2}$-minute quadrangles: House

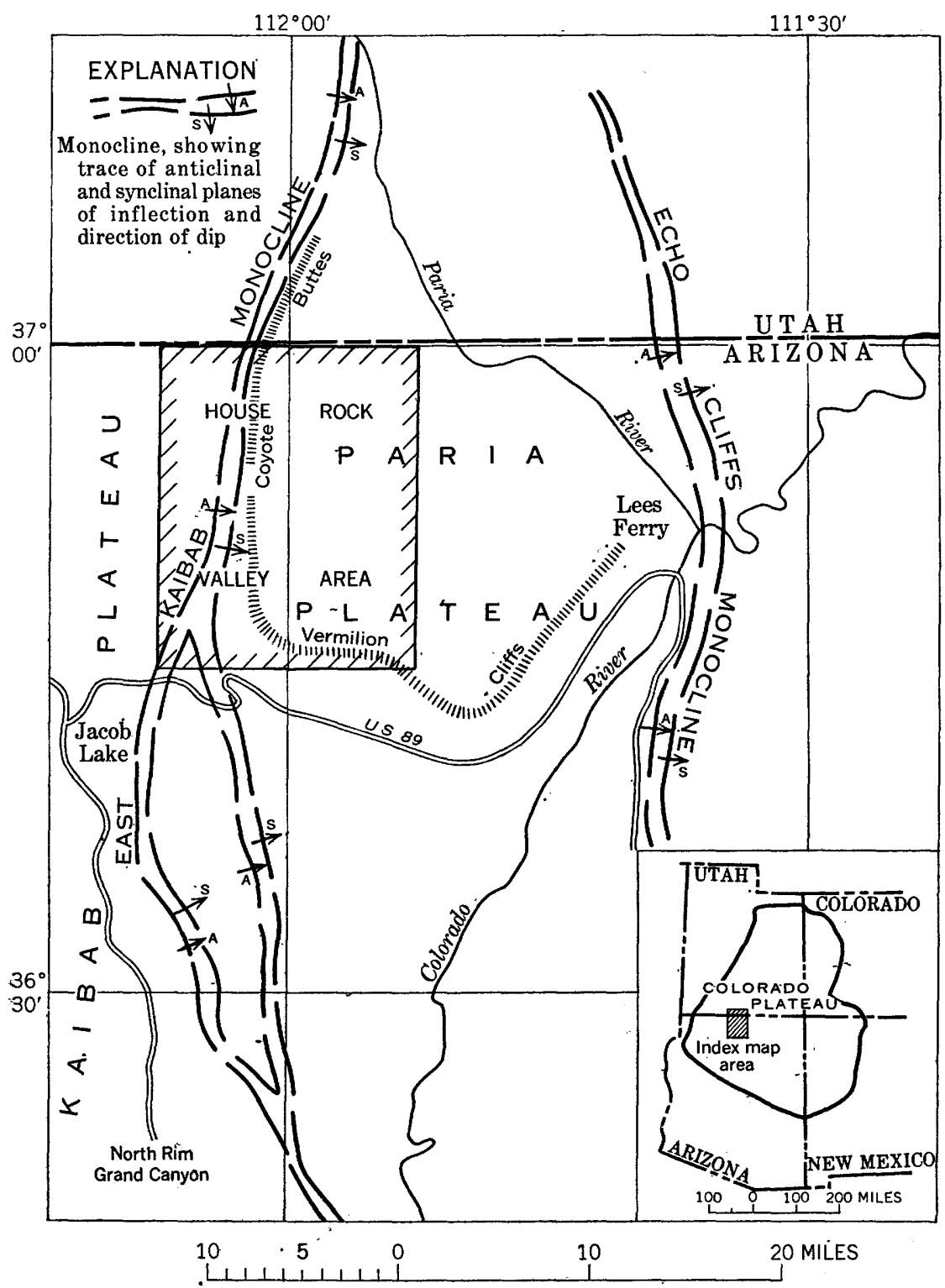

Frgurs 11.-Index map showing location of the House Rock Valley area, Coconino County, Ariz. 
Rock Spring NE, House Rock Spring SE, Paria Plateau NW, and Paria Plateau SW.

Fieldwork was begun in the summer of 1955 as part of the study of the east Vermilion Cliffs area. Most of the mapping was done in 1956 by the U.S. Geological Survey on behalf of the Division of Raw Materials of the U.S. Atomic Energy Commission. The topographic base maps (on a scale of 1:24,000 and a contour interval of 40 feet) were made by the U.S. Geological Survey from aerial photographs taken in 1953.

The area which includes part of the East Kaibab monocline, is in the west-central part of the Colorado Plateau province. The bedrock exposed ranges in age from Permian to Jurassic. Several types of Recent alluvial and landslide surficial deposits are exposed.

The climate of the area is semiarid to arid. The vegetation is typical for the Colorado Plateau and includes trees of pinyon, juniper, and at higher altitudes, ponderosa pine. Low desert bushes and grasses grow throughout the area. A detailed description of the climate and vegetation of a similar area, the Paunsaugunt region, is given by Gregory (1951, p. 8-15).

Surface altitudes in the area range from about 5,300 to 7,300 feet above sea level. Prominent topographic features in the area are: the East Kaibab monocline bounding the eastern part of the Kaibab Plateau, the Vermilion Cliffs bounding the Paria Plateau in the southeastern part of the area and Coyote Buttes bounding the Paria Plateau in the northern part of the area (pl. 4). In the western part of the area the rounded dip slope of the East Kaibab monocline is well shown by outcrops of resistant beds of the Kaibab limestone. The Vermilion Cliffs, the upper 1,000 feet of which are nearly vertical, stand about 1,800 feet above House Rock Wash in the southeastern part of the area. The cliffs are low and rounded in the central part; whereas Coyote Buttes, formed by the upturned Navajo sandstone, form a prominent ridge in the northern part of the area. House Rock Valley forms the depression between the Paria and the Kaibab Plateaus.

The streams are ephemeral with youthful to mature valleys. They form deep canyons where they cross the edges of plateaus, and open valleys on top of Paria Plateau and where the streams cross easily eroded rocks. Stream erosion occurs only during and shortly after periods of rainfall. Stream deposits occur mostly where the gradient is sharply reduced at the edge of the plateaus. Prominent alluvial fans are formed in this way east of the Kaibab Plateau.

The writer wishes to thank Charles U. Steele, who assisted in the fieldwork, and to thank the local ranchers and property owners for granting access to the area, for identification of geographic 
features, and for information on the history and development of the prospects, springs, and wells of the area.

\section{STRATIGRAPHY}

Rocks exposed in the House Rock Valley area range in age from Permian to Recent and are about 4,600 feet thick. The rocks of Permian age consist of marine limestone, gypsum, and white sandstone including some red siltstone. The rocks of Triassic and Triassic(?) age consist of red terrestrial siltstone and red and gray shallow marine mudstone, and terrestrial mudstone and sandstone. The upper Triassic and Jurassic and Jurassic(?) rocks consist of red terrestrial sandstone and siltstone; a large part of this, the Navajo sandstone, is eolian. Recent sediments consist of landslides, unconsolidated silt, sand, and gravel.

\section{PERMIAN ROCKS}

The Permian rocks, including the Hermit shale, Toroweap formation, and Kaibab limestone, are exposed on the Kaibab Plateau (pl.4). The Kaibab limestone forms the caprock of the plateau; and the Toroweap formation and Hermit shale are exposed only in the deep canyons.

\section{HERMIT SHALE}

The Hermit shale was named by Noble (1922, p. 26, 28, and 64) and includes red shale and sandstone of Permian age which overlie the Supai formation and underlie the Coconino sandstone. In the House Rock Valley area only about 20 feet of the upper part of the Hermit shale is exposed in an outcrop in Burro Canyon; here it is a red siltstone (see "Measured stratigraphic sections," section 1). The Hermit shale is overlain by the Toroweap formation. The Coconino sandstone is absent in the area, although it is 175 feet thick (R. G. Petersen, oral communication, 1957) in the Emmett Wash NE quadrangle about 25 miles to the southeast. Coarse, rounded, frosted quartz grains, which occur near the Hermit-Toroweap contact, mark the probable lateral equivalent of the Coconino sandstone.

\section{TOROWEAP FORMATION}

The Toroweap formation was named by McKee (1938, p. 12 and 17) and defined to include beds of sandstone, limestone, and gypsum underlain by the Coconino sandstone and overlain by the Kaibab limestone. The measured section in Burro Canyon (section 1) and incomplete exposures in the southwestern part of the area show that the basal part of the formation is dolomitic limestone and limy siltstone, and that the upper 145 feet is gypsum and anhydrite with thin beds of white and orange sandstone. The great thickness of gypsum seems 
to be limited in areal extent, as sections about 20 miles east (McKee, 1938, p. 209-210) and 15 miles north (Noble, 1928, p. 43) show no gypsum. The lower contact with the red beds of the Hermit shale is sharp and conformable. The unit is easily distinguished from the adjacent formations by the prominent gypsum. Poorly preserved casts of fossils occur in the lower limestone of the formation. McKee (1938) described these fossils in detail.

\section{KAIBAB LIMESTONE}

The Kaibab limestone was defined by Darton (1910, p. 21, 28, and 32 ) as the limestone which overlies the Coconino sandstone and underlies the Moenkopi formation. Modern usage excludes the lower part defined as Toroweap by McKee. In this report the Kaibab limestone has been divided into upper and lower units because of distinctive lithology and because a stratigraphic horizon was needed in order to draw a structural contour map of the East Kaibab monocline. The upper part of the Kaibab limestone is approximately equivalent to the alpha member as defined by McKee (1938, p. 50).

Lower part of the Kaibab limestone.-A measured section of this unit from Burro Canyon (p. 142, section 1) shows that it is 246 feet thick and consists predominantly of gray cherty fossiliferous dolomite and dolomitic limestone with white sandstone in the middle part. Incomplete exposures in the northern part of the area indicate that the lower part is mostly sandstone. The fossils are: brachiopods, crinoids, gastropods, pelecypods, corals, bryzoans, trilobites, and sponges; detailed descriptions of these are given by McKee (1938). The lower contact is conformable and sharp against gypsum beds of the Toroweap formation.

Upper part of the Kaibab limestone.-This unit is distinguished from the lower part of the Kaibab by the general yellowish-gray color, the ledgy slopes instead of cliffs, and the jagged pitted surface of the ledges. The unit is 132 feet thick in the southern part of the area and consists of a series of yellowish-gray resistant dolomite beds and sandstone interbedded with gray and red siltstones (p. 143 section 2 ). The lower contact at the base of a fractured vuggy chert bed, is sharp and conformable (section 2, unit 1). The fossils are a molluscan assemblange listed in measured section 2 , unit 8 .

\section{TRIASSIC ROCKS}

The Triassic rocks include the Moenkopi and Chinle formations along House Rock Wash, Coyote Wash, and south of the Vermilion Cliffs in the southeast corner of the area (pl. 4). Exposures of these rocks are generally poor, especially in the southern part of the area; 
near the north boundary exposures are fair. The upper part of the Chinle is generally well exposed along the Vermilion Cliffs.

\section{MOENKOPI FORMATION}

The Moenkopi formation of Early and Middle(?) Triassic age was named by Ward (1901, p. 401-413) and includes the red beds which unconformably overlie the Kaibab limestone and unconformably underlie the Chinle formation. In the wash west of Coyote Spring (pl. 4) the entire thickness of the Moenkopi formation is exposed; here the unit is 756 feet thick and consists of reddish-brown and greenish-gray siltstone which is partly cross stratified and ripple marked and locally is gypsiferous (p. 145, section 3). Because of generally poor exposures and lack of distinctive units the formation was not separated into members, although unit 5 in the measured section may be equivalent to the Shnabkaib member as defined by Bassler and Reeside (1921, p. 90-92) and recognized by Gregory $(1948$, p. 225) in Kane County, Utah. The lower contact is unconformable with only minor observed irregularities. It is marked by a very thin bed of fragmental material that might represent a basal conglomerate of the Triassic rocks.

\section{CHINLE FORMATION}

The Chinle formation of Late Triassic age was named by Gregory (1917, p. 42). Redefinition of the formation has included several members, three of which, the Shinarump (Stewart, 1957), Petrified Forest, and Owl Rock (I. J. Witkind and R. E. Thaden, written communication, 1960) members were recognized in this area. The Chinle formation is prominent and easily recognized in the area because of its characteristic rounded slopes that are gray in the lower part, and dark red in the upper part. In House Rock Valley the MoenkopiChinle contact is mostly concealed, but its inferred position is shown on plate 4.

Shinarump member.-The Shinarump member was first named by Gilbert $(1875$, p. 176). Recent redefinition of the unit by Stewart (1957, p. 442-444) includes it as a member of the Chinle formation.

The Shinarump member is absent in the southern part of House Rock Wash but is as much as 53 feet thick (p. 145-146, sections 4, 5) in the northern part of Coyote Wash (pl.4). The member consists of predominantly conglomeratic sandstone and coarse-grained sandstone; the pebbles are generally well rounded quartzite. The Shinarump is well cemented in most places, but at localities east of Burro Canyon and northwest of benchmark Fang the unit is entirely or partly unconsolidated. The consolidated Shinarump forms a prominent bed dipping mostly to the east. The lower contact is sharp, unconform- 
able, and even. No paleostream channels were observed although they are characteristic of the contact several miles to the east.

Petrified Forest member.-In central Kane County, Utah, an area adjacent to the House Rock Valley area, the name Petrified Forest member was applied by Gregory (1948, p. 229) to variegated and mottled sandstone, siltstone, bentonite, and mudstone which weather to mounds and rounded ridges. These beds are underlain by the Shinarump member and overlain by red sandstone of the Glen Canyon group that is exposed in the Vermilion Cliffs. In the House Rock Valley area the Petrified Forest member is a variable unit of interbedded bentonitic mudstone, siltstone, sandstone, and conglomeratic sandstone colored different shades of red, gray, yellow, green, brown, and purple (p. 146, 149, 152, secs. 6, 7, 8). The lower part of the unit is predominantly gray mudstone and the upper part mostly dark red interlensed and interbedded mudstone, siltstone, and poorly cemented sandstone. Where weathered the sandstone forms subdued ledges and the siltstone and mudstone form characteristic rounded slopes and knolls which have a frothy-appearing surface. The thickness in the northern part is 810 feet and probably thins somewhat to the south. Locally, in the Lees Ferry area, about 30 miles east, prominent uranium mineral-bearing white sandstone ledges occur in the lower part of the unit; these are generally absent in the House Rock Valley area. Petrified logs which occur commonly in other areas are sparse here.

The lower contact, where observed, is conformable and gradational with the Shinarump member. Where the Shinarump is absent a sharp unconformable contact exists with the Moenkopi formation. In the northern part of the area a zone of "purple-white" siltstone beds occur in the Petrified Forest member near the contact with the Moenkopi.

One identifiable fossil, "Unio" graciliratus Simpson," was found in the upper part of the unit. This fossil has been described from beds of the Dockum group, Upper Triassic of west Texas (Simpson, 1896).

Owl Rock member.-The name "Owl Rock member" was applied by Irving J. Witkind (written communication, 1960) to beds exposed in the Monument Valley area, Arizona. The rocks mapped as Owl Rock in the House Rock Valley are similar to those in the type locality and are probably correlative with them (J.H. Steward, oral communication, 1957).

The Owl Rock member in the House Rock Valley area consists of predominantly dark red slightly bentonitic to nonbentonitic mudstone; in the Four Springs area nodular limestone ledges are present (p. 146, 149 , secs. 6 and 7 ). The unit is absent in the southeastern part of the area (pl. 4) but in the northern part of the area it ranges in thickness

a Identified by John B. Reeside, Jr., U.s. Geological Survey. 
from 45 feet at Coyote Spring to 53 feet at Four Springs in the central part. The line of pinchout is covered by surficial deposits south of Four Springs. The lower contact is not conspicuous as the beds above and below the contact are nearly the same color. Bentonitic sandy beds occur immediately below the contact in this area; above the contact the slopes weather to a granular-appearing surface in contrast to the frothy-appearing surface of the highly bentonitic beds below.

\section{TRIASSIC(?) ROCKS}

\section{MOENAVE FORMATION}

The Moenave formation of Late Triassic(?) age was defined in the Navajo Country by Harshbarger and others (1957, p. 12) as sandstone that overlies the Wingate sandstone or Chinle formation and underlies the Kayenta formation; it consists of an upper cliff-forming unit and a lower slope-forming unit. These two units were defined as members of the Moenave formation and assigned names that had been previously used. The lower unit had been named the Dinosaur Canyon sandstone member by Colbert and Mook (1951) and the upper unit had been named the Springdale sandstone member by Gregory $(1950$, p. 67$)$. These beds were traced by Harshbarger and his coworkers into the Vermilion Cliffs and House Rock Valley areas.

The Moenave formation comprises the lowest part of the Vermilion Cliffs in the House Rock Valley area. The outcrops are good except between Coyote Wash and House Rock Wash.

Dinosaur Canyon sandstone member.-In the House Rock Valley area the Dinosaur Canyon sandstone member consists predominantly of red coarse- to fine-grained thin- to thick-bedded siltstone and mudstone that weathers to a ledgy slope (sections 6,7, and 8). A 15-foot variegated mudstone in the middle part of the member in the southern part of the area contains a fresh-water ostracode resembling Darwinula? and a conchostracan. ${ }^{2}$ Fossil fish remains were found near the upper contact at Four Springs. Schaeffer and Dunkle (1950) have described these remains and consider them to be of Triassic age. The thickness ranges from 143 feet in the southern part of the area to 100 feet at Four Springs to 170 feet at Coyote Spring (pl. 4). The lower contact is sharp, conspicuous, and comformable against the dark-red mudstone of the Chinle formation.

Springdale sandstone member.-The Springdale sandstone member consists of pale reddish-brown medium-grained micaceous sandstone that forms a prominent cliff in which siltstone and conglomerate lenses are conspicuous in the otherwise massive formation (sections 6, 7, and 8). The Springdale resembles some of the thick ledges of the

Identified by I. G. Sohn, U.S. Geological Survey. 
Kayenta formation but distinction is possible because of the generally coarser grain size and purplish cast of the beds of the Springdale in contrast to those in the Kayenta. The thickness ranges from 140 feet in the southern part of the area to 155 feet in the Four Springs area to 200 feet near Coyote Spring (pl. 4). The lower contact is conformable and gradational.

The variations in combined thickness of the Dinosaur Canyon sandstone member and the Springdale sandstone member show a marked thickening of the Moenave formation to the north. The thickness of the formation ranges from 283 feet in the southern part to 255 feet at Four Springs to 370 feet near Coyote Spring.

\section{JURASSIC (?) ROCKS}

\section{KAYENTA FORMATION}

The Kayenta formation was named by Baker and others (1931) for beds that overlie the Wingate sandstone and underlie the Navajo sandstone near Kayenta, Ariz. In the House Rock Valley area the Wingate is absent and the Moenave formation underlies the Kayenta. The Kayenta formation is continuous from the type locality to the House Rock Valley area.

In the House Rock Valley area outcrops of the Kayenta are nearly continuous along the Vermilion Cliffs (pl. 4), where the Kayenta forms the slope below the prominent cliffs of the Navajo sandstone. The Kayenta formation consists of a sequence of alternating beds of moderate reddish-brown sandstone and siltstone that forms a ledgy slope with ledges and cliffs 10 to 20 feet high (sections 6,7 , and 8 ). The siltstone contains thin light greenish-gray layers. Several thin white sandstone beds are conspicuous in the Four Spring area; these beds become less abundant to the north, and are absent in the northern part of the area. The siltstone is thin bedded and locally crossbedded on a small scale and the sandstone is thin to thick bedded, ripple marked, and crossbedded on a small to medium scale. Thin lenticular conglomerate beds of angular siltstone fragments are common. The thickness ranges from 285 feet in the southern part of the area to 312 feet at Four Springs to 230 feet near Coyote Spring. The lower contact is sharp and conformable.

\section{JURASSIC AND JURASSIC(?) ROCKS}

\section{NAVAJO SANDSTONE}

The Navajo sandstone of Jurassic and Jurassic(?) age forms the prominent well-joined upper part of the Vermilion Cliffs and is the surface rock of nearly all the Paria Plateau (pl. 4). The Navajo sandstone was named by Gregory $(1915$, p. 102, 112) for the light-red massive crossbedded sandstone on the Navajo Indian Reservation. 
The Navajo sandstone of the House Rock Valley area is continuous with the formation exposed at the type locality.

In the House Rock Valley the Navajo sandstone is reddish orange in the lower part and white in the upper part and consists of mostly rounded frosted quartz grains (sections 6, 7, and 8). Locally lenses of red sandy dolomite occur in the sandstone. Large-scale tangential cross stratification is commonly conspicuous, but in some areas the rock is nearly massive where there is little cross stratification. In other areas the cross strata have been crumpled, probably by slumping during deposition. A plot of 137 measurements of the attitude of the cross strata show that during deposition the wind was from the northwest and northeast, with $\mathrm{N} .60^{\circ} \mathrm{W}$. the most common direction; winds from the south were rare.

No complete sections of the Navajo sandstone are in the area, but calculations made from exposures in the Paria Plateau NE quadrangle, immediately east of the House Rock Valley area, show that the Navajo below the tongue of the Carmel is about 1,700 feet thick. The tongue of Navajo sandstone above the tongue of Carmel is absent everywhere due to erosion, except for one small area near White Pocket in the northeastern part of the Paria Plateau NW quadrangle.

The lower contact of the Navajo sandstone is sharp, conformable, and generally distinctive, and marked by the base of the large-scale tangential eolian-type cross stratification. In the area east of Coyote Spring (pl. 4) the contact is poorly defined because here the Navajo is fine grained, much like the Kayenta formation, and the cross stratification is indistinct.

\section{JURASSIC ROCKS \\ CARMEL FORMATION}

The Carmel formation was named by Gilluly and Reeside (1926) for rocks exposed near Mount Carmel, Utah; the formation was described by Gregory and Moore (1931, p. 69).

In the House Rock Valley area the unit mapped as Carmel formation is a tongue about 5 feet thick and consists of red limestone and calcareous siltstone and sandstone interbedded with white and red Navajo-like sandstone which is composed largely of rounded frosted quartz grains (section 9). The Navajo-like sandstone beds are probably part of the Navajo sandstone which is intertongued on a small scale with the Carmel formation. The lower contact is sharp and conformable with the main part of the Navajo standstone; the upper contact of the tongue of Carmel formation is poorly exposed but apparently gradational into the tongue of Navajo sandstone above.

The tongue of Carmel exposed in this area joins the main body of the Carmel about 35 miles northwest of the area, and pinches out about 15 miles east (J. C. Wright and D. D. Dickey, written communication, 1957). 


\section{QUATHRNARY DEPOSTTS}

Five types of Quaternary deposits were mapped in the House Rock Valley area : landslide blocks, landslide debris, sand, alluvial fans, and alluvium. These units have gradational boundaries and are partly contemporaneous.

\section{LANDSLIDE BLOCKS}

The landslide blocks are large segments of the Vermilion Cliffs that have slid down and out with a rotational motion so that the blocks now dip as much as $40^{\circ}$ toward the cliff (pl. 4). During the sliding, the beds in these blocks were mostly undisturbed, therefore, the stratigraphy of the blocks has been mapped and the postscript $(s)$, added to the map formation symbol. The rock units mapped are: Petrified Forest member of the Chinle formation, Dinosaur Canyon sandstone member and Springdale sandstone member of the Moenave formation, Kayenta formation, and Navajo sandstone.

The zone or surface upon which the sliding of the blocks occurred is in the lower part of the Petrified Forest member of the Chinle. This is a plastic unit and extremely weak when water saturated.

As pointed out by Strahler (1940) the slides are of several ages. The slides furthest from the cliff are in the most advanced stage of disintegration and are therefore the oldest, whereas those near the cliff are only slightly disintegrated and the youngest. Small faults and open joints in the Navajo sandstone of the cliff indicate that the early stages of a forthcoming slide are now in progress.

\section{LANDSLIDE DEBRIS}

The unit mapped as landslide debris is gradational and consists of landslide blocks in which breakage during sliding was so extensive that mapping of the stratigraphic units was impractical or impossible. Landslide debris is exposed along the Vermilion Cliffs mainly in the southeastern part of the area (pl. 4). The unit varies from partly disturbed blocks of the cliff to a poorly sorted jumbled mass of angular fragmental debris ranging in size from boulders to sand; this forms a hummocky topography. Some of the material in this unit consists of cone-shaped colluvial deposits of fragmental material currently accumulating along the cliff. Thin or small deposits of sand similar to that described below are in the unit. The cone-shaped colluvial deposits and the sand were not mapped separately because of their small areal extent.

\section{SAND}

The unit mapped as sand consists of unconsolidated red, medium- to fine-grained, silty sand which is largely wind deposited but partly reworked by surface water. The unit ranges in thickness from a few feet to a few tens of feet and forms a rounded uneven surface. The sand is restricted almost entirely to the east side of House Rock Wash 
and Coyote Wash (pl. 4). Large areas of sand which are a few feet. thick but locally 10 to 20 feet thick occur on the Paria Plateau. No effort was made to delimit the thick sand deposits on the Paria Plateau, because it would have been extremely time consuming and the boundaries mapped could only have been approximate.

\section{ALLUVIAL FANS}

The alluvial fans occur on the east side of the East Kaibab monocline where the gradient of the streams from the Kaibab Plateau is sharply reduced. The fans from the several streams coalesce and form a continuous deposit which covers the pediment between the monocline and House Rock Wash and Coyote Wash (pl. 4). The unit consists of poorly sorted, mostly unconsolidated angular limestone boulders and limestone and flint gravel derived largely from the Kaibab limestone. The thickness ranges from a few feet to about 20 feet. The basal few feet of the unit is generally consolidated. The lower contact forms an angular unconformity on the dipping Triassic beds below.

A few limestone boulders on the east side of Coyote Wash, 20 to 30 feet above the streambed, as well as the high-level pediment terraces west of the stream, indicate that the fan extended entirely across the valley at one time. Two levels of pediment deposits in the mapped area, and a few miles south of the House Rock Valley as described by Miller (1950), indicated the probable accuracy of Miller's proposal that two periods of gravel deposition occurred with erosion before, between, and after the periods.

\section{ALLUVIUM}

The unit mapped as alluvium in this area is restricted to recent. water-deposited material along present larger streams. Most of the alluvium is in House Rock Wash and Coyote Wash with small deposits on the Kaibab Plateau (pl.4). The alluvium consists of a few feet of poorly sorted angular limestone and flint gravel with red sand and silt. Much of the surficial material along the larger streams is of the same age and of similar origin as the alluvial fans.

\section{STRUCTURAL GEOLOGY}

The tectonic structures-folds, faults, and joints-in this area are typical of the Colorado Plateau. The most prominent structure is the East Kaibab monocline which extends 130 miles from the Grand Canyon, Ariz, northward to near Henrieville, Utah (Kelley, 1955, fig. 2). In the area covered by this report the regional trend of the monocline changes from about N. $20^{\circ} \mathrm{W}$. south of the area to about. N. $20^{\circ}$ E. north of the area (fig. 11). The Kaibab Plateau is west. 
of and about 3,500 feet structually higher than the Paria Plateau. Minor anticlines and synclines trend north and northeast on the Kaibab Plateau; low-amplitude anticlines trend subparallel to the monocline of the Paria Plateau. High-angle faults with offsets of as much as 700 feet, are nearly parallel to the regional monoclinal trend; faults with small offsets are both parallel and tangential to the trend. Joints are abundant throughout the area and form sets related to both the faults and folds. The regional dip of northern Arizona is about $2^{\circ} \mathrm{N}$.

Other prominent structures probably related to the East Kaibab monocline occur in northern Arizona. About 10 to 15 miles west of the East Kaibab monocline is a series of three generally northwardtrending high-angle faults which form the west side of the Kaibab Plateau (Strahler, 1948). These are arranged en echelon and the rocks on the west side are downthrown several hundred feet; many small faults and folds are associated with the faults. The Echo Cliffs monocline, about 25 miles east of the East Kaibab monocline (fig. 11), trends generally north and is structurally lower on the east side. Between the East Kaibab and Echo Cliffs monoclines are several lowamplitude broad anticlines and synclines that trend north nearly parallel to the monoclines.

The age of the East Kaibab monocline is known only by indirect geologic evidence from a similar monocline in the Circle Cliffs area in Utah. The Circle Cliffs upwarp is truncated by Paleocene sedimentary rocks, indicating a Late Cretaceous or early Paleocene age for the folding (Hunt, 1956, p. 73). Hunt states that presumably the Kaibab monocline was formed at nearly the same time as the Circle Cliffs folds.

\section{FOLDS}

The folds in this area are separable into six types on the basis of differences in size, shape, and association with faults or other folds. These types of folds are: (a) Monoclines, namely the East Kaibab monocline, (b) small drag folds associated with the monocline, (c) small cross folds that trend diagonally across the monocline on the upthrown side, (d) low-amplitude anticlinal and synclinal warps on the downthrown side of the monocline, (e) folds occurring as extensions of faults, and (f) drag folds adjacent to faults.

The East Kaibab monocline, the largest structural feature in this part of the Colorado Plateau, is about 130 miles long and has a maximum structural relief of about 3,500 feet; the west side is upthrown. The regional trend of the East Kaibab monocline is about N. $10^{\circ} \mathrm{E}$., but as the trace of the axial plane is convex to the west, the southern part trends N. $20^{\circ} \mathrm{W}$, and the northern part N. $20^{\circ} \mathrm{E}$. The mapped area covers the part of the monocline where the trends change (fig. 11). 
In the area covered by this report it trends on the average about $\mathrm{N}$. $7^{\circ} \mathrm{E}$. with the limb dipping as much as $30^{\circ}$ but generally between $10^{\circ}$ and $20^{\circ} \mathrm{E}$. South of the mapped area the East Kaibab monocline is a double monocline (Babenroth and Strahler, 1945, p. 134 and pl. 7). The east monocline trends N. $20^{\circ} \mathrm{W}$., and the west monocline trends N. $10^{\circ} \mathrm{E}$., the two join northward to form a single monocline in the southwest corner of the area.

Graphical plots of the average bearings of the folds and the attitudes of the faults and joints are shown (fig. 12) so that comparisons may be made between the orientations of the monocline, the anticlines and synclines, the faults, and the joints. Figure 12, plot 1, shows the average bearings of the three prominent trends of the monocline (pl. 5). Plot 2 shows the average bearing of the anticlines and synclines associated with the monocline (pl. 5). Plot 3 shows a stereographic plot of the average strike and dip of the faults (pl. 5). Plot 4 shows the streographic plot of the average strike and dip of joints. The average attitude of the joints was determined by a plot of 380 joint readings on an equal-area net.

On figure 12, plot 1, the line of trend $M-1$ represents the minor northeast monoclinal trend in the southwest corner of the area (pl. 5). The main trend of the monocline, $\mathbf{M}-2$, represents the general trend as shown in the central part of the map. The minor northwest trend of the south-central part of the area is shown by $\mathbf{M}-3$.

The structural surface of the East Kaibab monocline has many irregularities in strike and dip, as shown by the contours (pl. 4), and by the trace of the anticlinal and synclinal bends on the tectonic map (pl. 5). The trace of the anticlinal and synclinal bends of the monocline is drawn at the line of the most abrupt change between the steep and flat parts of the monocline as shown by contours on the base of upper part of the Kaibab limestone. These irregularities vary from major changes in the trend of the monocline to minor warps on the upthrown side of the monocline to very small local irregularities. The changes in the trend of the monocline are shown (pl. 5) by short southeastward-plunging anticlines and synclines west of Coyote Spring, and south of Burro Spring shown near the edge of the map. A series of low-amplitude anticlinal and synclinal flexures occur on the upthrown side of the monocline. The trend of most of these, N. $45^{\circ}$ to $55^{\circ} \mathrm{E}$., is diagonal to the monoclinal trend, but some parts of the flexures and some individual flexures trend northsouth about parallel to it. The flexures are gentle undulations that do not extend across the steep limb of the monocline. The short southeastward-plunging fold axes that indicate changes in the monoclinal trend are nearly perpendicular to the bearing of the flexures on the upthrown side of the monocline. 


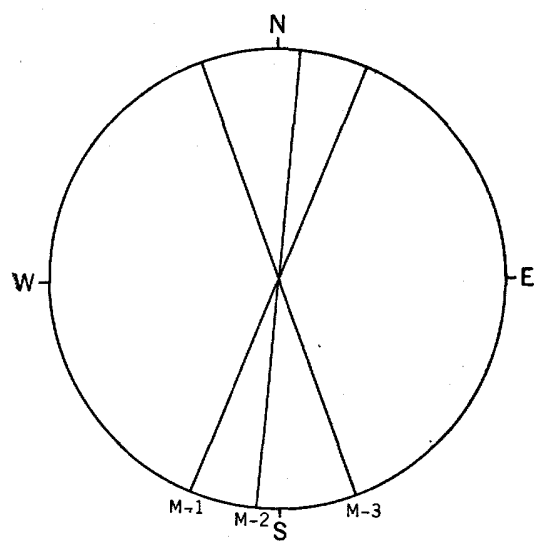

1. Monoclinal fold: $M-1$, minor northeast monoclinal trend; $M-2$, major mono. clinal trend; $M-3$, minor northwest monoclinal trend.

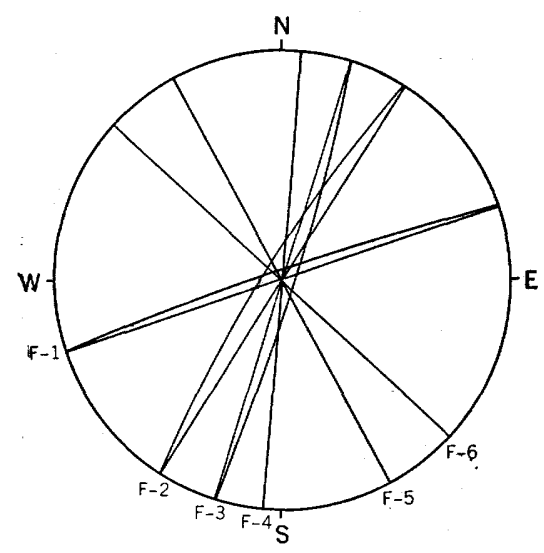

3. Faults: $F-1$, cross fault; $F-2$, paraliel to diagonal fold $A-1 ; F-3$, subparallel to main and minor monoclinal trends $M-1$ and $M-2 ; F-4$, parallel to main monoclinal trend $\mathrm{M}-2 ; \mathrm{F},-5$, subparallel to minor northwest monoclinal trend $M-3 ; F-6$, diagonal tault.

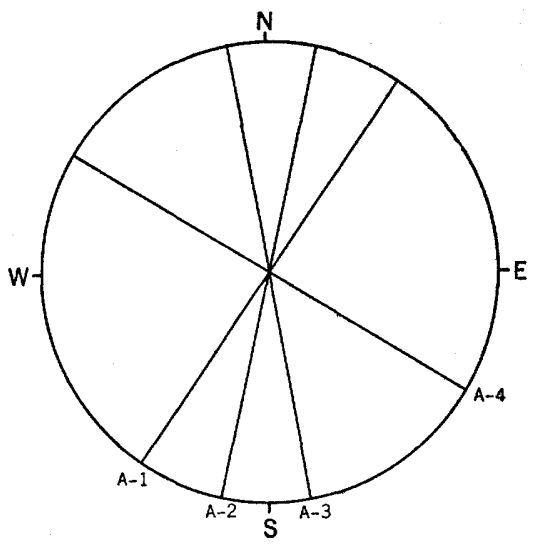

2. Folds associated with the monocline: $A-1$, folds diagonal to monocline: $A-2$, folds subparallel to major monocline; A-3. folds subparallel to minor northwest monoclinal trend; A-4, bends in mono. clinal trend.

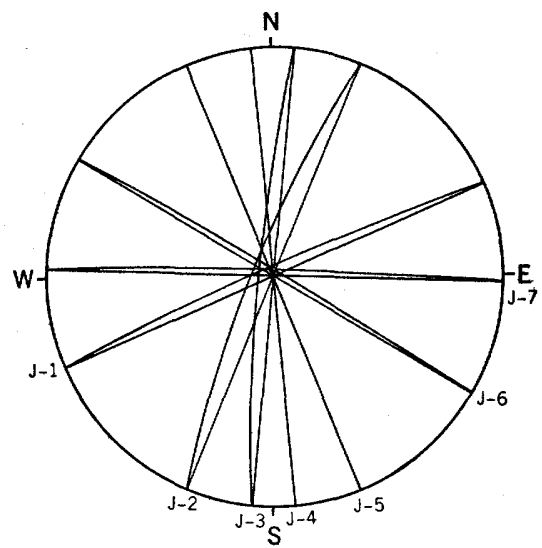

4. Joints: $\rfloor-1$, parallel to cross fault $F-1$; $J-2$, parallel to minor northeast mono. clinal trend $\mathrm{M}-1 ; \mathrm{J}-3$, parallel to major monoclinal trend $\mathrm{M}-2 ; \mathrm{J}-4$, parallel to folds subparallel to major monoclinal trend; $J-5$, subparallel to minor north. west monoclinal trend $M-3 ; J-6$, parallel to bends in monoclinal trend $A-4$; $\mathrm{J}-7$, cross joint perpendicular to major monoclinal trend.

Figdre 12.-Graphic plots of the average bearings of fold axes and stereographic plots of the average attitudes of faults and joints.

East of the monocline (pl. 5) are broad, low-amplitude anticlines and synclines. The major syncline bears about N. $5^{\circ} \mathrm{W}$. in the southern part and N. $25^{\circ} \mathrm{E}$. in the northern part. The shorter anticline to the east trends about N. $40^{\circ} \mathrm{E}$. The longer anticline joins the shorter anticline just south of the area mapped and forms a single anticline that, 4 miles south of the area, trends about N. $12^{\circ} \mathrm{E}$.

The average trends of the folds associated with the East Kaibab monocline are shown graphically on plot 2 in figure 12. The line A-1 
represents the axes of folds on the upthrown side of the monocline that trend diagonally to the major monoclinal trend; A-2 represents folds on the upthrown side of the monocline in the northwestern part of the area that are subparallel to the major trend; A-3 represents the low-amplitude folds immediately east of the monocline that are subparallel to the minor northwest trend; and $A-4$ represents the axes of cross folds on the steep limb of the monocline formed at the changes in the regional trend.

Small anticlinal and synclinal folds in the Shinarump member of the Chinle formation, which have a trend nearly parallel to that of the monocline, are exposed in Coyote Valley (pl. 4). These folds are asymmetrical, having eastward-dipping axial planes; most of the dips to the east are about $10^{\circ}$ less than those to the west. High-angle faults with small offsets are commonly associated with these folds.

Small folds associated with major faults represent frictional drag adjacent to the faults and extensions of the structural off set beyond the ends of the faults. Both types of folds are shown with the faults 2.5 miles south of Burro Spring in the southwest corner of the House Rock Valley area.

\section{FAULTS}

The faults that occur in the House Rock Valley area vary widely in length, amount and type of displacement, and trend. The length ranges from a few miles to a few tens of feet and the displacement from a few feet to about 700 feet. The faults are mostly steep and the displacement is always nearly parallel to the dip direction. Both normal and reverse faults occur; the east side if downthrown on some, whereas the west side is downthrown on others; and a few pivotal faults occur. Some of these faults are nearly parallel to the monocline, and occur on its steep limb. Others, striking at large angles to the nonocline, occur on both the upthrown and downthrown sides.

The faults are locally uniform in strike and dip but regional variations of $10^{\circ}$ to $20^{\circ}$ are common. The dips of a few of the faults change from nearly vertical to nearly $45^{\circ}$ between the central and end parts. Associated small to large drag folds are common in the Permian and Triassic rocks. The character of the fault zone varies with the type of rock that is faulted. The faults in the Permian limestone form poorly defined and poorly exposed brecciated zones that range from a few feet to a few tens of feet in width. Slickensides are rare. In the incompetent rocks of the Moenkopi and Chinle formations the faults are sharp but generally poorly defined. In the Shinarump they are sharp and well defined by a thin zone of crushed and recrystallized quartz. These silicified surfaces commonly show slickensides. The Triassic and Jurassic sandstones contain faults that form both sharp fractures and wide fault zones. Individual shears in 
these zones commonly are marked by thinly crushed and recrystallized zones similar to those in the Shinarump. Calcite is a fissure filling in some of the faults in the sandstone.

The faults with the largest displacements, 300 to 700 feet, occur on the steep limb of the monocline and are nearly parallel to its trend. The displacement along these faults differs, so that the relief of the monocline is increased by some faults but is decreased by others. The faults in the southwest corner and in Coyote Valley near the north boundary of the area (pls. 4 and 5) decrease the structural relief of the monocline, whereas displacement of the faults in the northern part of House Rock Valley increases the structural relief. A fault that increases the structural relief as much as 1,300 feet extends from the Utah State line north-northeastward for about 15 miles along the monocline. Drag folds occur along the faults that decrease the structural relief and the faults extend into synclines that die out rapidly. Folding is not known to be directly associated with the faults that increase the monoclinal relief.

High-angle faults with displacements of generally about 20 feet but as much as 150 feet, occur on the structural flats above and below the monocline. These faults strike generally northwest or northeast at large angles to the monocline; east of the monocline they strike predominantly northwest, whereas to the west they strike predominantly northeast. Some of them have the east side downthrown, others have the west side downthrown; some are paired to form horsts or grabens whereas others form a series of step faults.

High-angle faults, most of which have displacements of less than 20 feet, occur on the steep limb of the monocline in the north-central part of the area (pls. 4 and 5). Most of these trend about N. $10^{\circ} \mathrm{E}$., nearly parallel to the monocline but some of them trend about N. $35^{\circ}$ W. and N. $55^{\circ}$ E. As most of the offsets are in the Shinarump member of the Chinle formation and can be traced only short distances into the rocks above and below, these are probably minor faults restricted mostly to the Chinle and Moenkopi formations. Along some faults the east side is downthrown, along others the west side is downthrown. Just north of Coyote Spring, small folds outlined by the Shinarump member are accentuated by the fault displacement.

Small faults in the south-central part of the map, in the Vermilion Cliffs, seem to be local features because the displacement is only a few feet and they extend only a few hundred feet from the cliff face. Also, the faults are restricted almost entirely to the Navajo sandstone, extending a few tens of feet downward into the Kayenta formation. These faults seem to be related to the large slump blocks that occur along the cliff.

Thrust faults with displacement of a few feet have been observed in the Petrified Forest member of the Chinle formation in House Rock 
Valley and near the base of the Navajo sandstone along Coyote Buttes. Some of the faults dip flatly to the east, others dip to the west. The beds adjacent to some of the faults have been drag folded. Some of the flat faults in the Navajo sandstone along Coyote Buttes are marked by a zone of pulverized sandstone a few inches to a few feet wide.

The average strike and dip of faults in the area is shown graphically on stereographic plot 3 in figure 12. The faults represented by $\mathbf{F}-1$, occur mostly in the northwestern part of the area (pls. 4 and 5), and are cross faults that strike at an angle of nearly $70^{\circ}$ to the major monoclinal trend; F-2 is a series of faults occurring mostly on the steep limb. of the monocline that parallel the diagonal folds on A-1, the upthrown side of the monocline; F-3, also occurring in the steep limb of the monocline, is subparallel to the minor northeast and major monoclinal trends $\mathbf{M}-1$ and $\mathbf{M}-2 ; \mathbf{F}-4$ represents the faults with small offsets occurring in the northern part of Coyote Valley that are parallel to the main monoclinal trend; F-5 represents faults which occur mostly in the northeast corner of the area and are subparallel to the minor northwest monoclinal trend; F-6 which is a diagonal fault zone striking at about $45^{\circ}$ to the major monoclinal trend, occurs in the central part of the area east of the monocline.

Zones of intense shearing occur in the Triassic and Jurassic rocks. These are most pronounced in the Shinarump member of the Chinle formation, the Kayenta formation and Navajo sandstone. The zones consist of nearly vertical faults spaced a few inches apart with offsets of a fraction of an inch; the surfaces of faults have slickensides. In the Shinarump member the slickensides may be nearly vertical on one fault surface and nearly horizontal on an adjacent fault surface. The small faults intersect at angles of $5^{\circ}$ to $10^{\circ}$. Deformation and recrystallization of the quartz grains along the fracture make this part of the rock more resistant to weathering and as a result a boxwork is formed on erosion surfaces.

Measurements of the attitude of the shear surfaces and the bearing and plunge of the slickensides with the direction of movement were taken at three localities in the Shinarump member of the Chinle formation (pl.4). Two sets of measurements ( $A$ and $B$ ) were made in the southern part of Coyote Valley in the northeast corner of sec. 15, T. 40 N., R. 3 E.; a third set $(C)$ was made at exposures along Coyote Wash in the northern part of the area in the western part of sec. 1 , T. 41 N., R. 3 E. The exposure of the shear zones at $A$ and $B$ are on the flanks of a small anticline that plunges to the north. Exposure $A$ is on the east limb of the anticline, and exposure $B$ is on the west limb.

At exposure $A$ the shear surfaces strike in two preferred directions; north-south and slightly north of northeast. Most of the surfaces that strike north-south dip nearly vertically to the west; the northeaststriking surfaces dip less steeply to the southeast. Most of the slicken- 
sides have a bearing of nearly north or south regardless of the strike and dip of the surfaces they appear on. All plunges of less than $15^{\circ}$ are to the north; steeper plunges are to the south, the amount dependent upon the strike and dip of the fault surface that shows them. The west sides of faults with northward-plunging slickensides are generally displaced to the south and the west sides of faults with southward-plunging slickensides have moved down. The bearing of the slickensides is virtually parallel to the strike of the beds in the outcrop and the major monoclinal trend. Some of the slickensides on the northeastward-trending shears plunge about $70^{\circ} \mathrm{E}$.

At exposure $B$ the shear surfaces mostly strike east-northeast parallel to the local strike of the beds, and dip steeply to both the northwest and southeast. Most of the slickensides have a bearing generally parallel to the strike of the shears and are nearly horizontal or plunge moderately steep to either the northeast or southwest. Some of the shear surfaces and slickensides are about parallel to the northwardsouthward-trending group in exposure $A$.

Exposure $C$ is in an area of short faults with small displacements that strike generally north and north-northeast and dip nearly vertical. The beds strike north-south and dip east. The shear surfaces associated with these mostly strike parallel to the strike of the faults and the beds, and have dips that are generally moderately steep toward the east and west. The slickensides indicate mostly east and west, virtually dip-slip, movement. Some faults that strike nearly east-west have strike-slip movement. Slickensides on other shears bear south-southwest.

Although the attitude of the shear surfaces and slickensides exhibit preferred orientation within single exposures the variations between exposures are marked. In general the shears and slickensides appear to be more nearly associated with local bedding and faulting features than to any regional features.

Shear zones are prominent in the Kayenta formation and Navajo sandstone in the Coyote Buttes and in the Navajo along faults in the eastern part of the area. Near the east margin of the shear zone along Coyote Buttes, crossbedded sets in the Navajo sandstone consisting almost entirely of sand are sheared, whereas those sets that consist of interlaminated sand and clayey silty sand are not sheared. Apparently shearing could only take place by fracturing in the uniformly competent rock while the clayey parts of the heterogeneous rock offered alternative planes of slippage.

Shearing represented by slickensides in the Chinle formation and to a lesser extent in the Moenkopi along Coyote Valley occurs in the area of bending on the east side of the monocline. In a similar structural environment near the top of the Kayenta formation random 
displacements of keystonelike joint blocks of a few feet formed horsts and grabens. Steep slickensides occur on the surfaces of these blocks.

\section{JOINTS}

Joints are prominent in all of the competent rocks of the House Rock Valley area. They are sharply defined in the Moenave and Kayenta formations and the Navajo sandstone along the Vermilion Cliffs, where single joints form the sheer walls of the cliff. The joints in the limestone of the formations of Permian age and the sandstone and siltstone of the Moenkopi and Chinle formations are abundant and well defined although not as extensive as those in the sandstone formations along the Vermilion Cliffs. Joints are poorly defined in the mudstone of the Chinle formation.

Practically all of the dips are greater than $75^{\circ}$ and many are almost vertical. Several preferred directions of jointing are present in the area. The average strikes and dips of these joint directions are shown on the stereographic plot 4 on figure 12. This stereographic plot was constructed by the transfer of the data from an equal-area plot of 380 joint readings in all rock units in the area.

The joint directions are all parallel to either folds or faults in the area. The joint designated J-1 (fig. 12, plot 4) is parallel in both strike and dip to the cross fault, F-1 (fig. 12, plot 3). Joint direction $\mathrm{J}-2$ is parallel to the minor monoclinal trend in the southwest corner of the area. $\mathrm{J}-3$ is parallel to the major monoclinal trend $\mathrm{M}-2 ; \mathrm{J}-4$ is parallel to the main trend of the low-amplitude folds east of the monocline; $J_{-5}$ is subparallel to the minor northwest monoclinal trend in the south-central part of the area; $J-6$ is parallel to the axes of the folds formed by changes in the regional monoclinal trend; and $J-7$ is a cross joint perpendicular to the major monoclinal trend.

Aerial photographs of the Paria Plateau east of the East Kaibab monocline show joints prominently marked by vegetation. The joints show a pattern of intersecting arcuate and straight lines. The several directions represented in this pattern are parallel to some of the joint directions shown on stereographic plot. The arcuate lines are prominent in the synclinal bend of the monocline; here the joint directions change from northeast, east of the monocline, to east-west on the steep limb of the monocline. In this locality the joints maintained a strike nearly perpendicular to the line of strike as shown by the structure contours.

The data discussed here and presented in figure 12 and plate 5 do not clearly indicate the direction and type of forces that caused these structures. A detailed study of a greater part of the East Kaibab monocline is necessary before any conclusions may be reached. Therefore, only statements about local relationships can be made. 
Compressional forces operated at least locally, as shown by the thrust faults, slickensides, and shearing of the sandstone. The zone of compressional features is restricted to a band along the synclinal bend of the monocline and is probably the result of local compression on the inside of the fold.

The small folds in the Shinarump member of the Chinle formation in the northern part of the area (pl. 4) possibly are caused by drag folding from differential movements of the beds during the folding of the monocline. The Permian beds would move down the limb of the monocline relative to the Triassic and Jurassic sandstones. This movement could cause drag folding in the incompetent Moenkopi and Chinle formations similar to that in the Shinarump member.

The minor faults that form horsts and grabens indicate that at least local tensional forces may have operated on the outside of the folds. The monocline and the major faults that increase the relief were probably formed at the same time, assuming that the monocline was formed over a deeply buried fault zone. An origin for the major faults that decrease the relief of the monocline is difficult to suggest unless these faults are related to the faults with similar offsets on the west side of the Kaibab Plateau.

The parallelism of certain groups of folds, faults, and joints suggests a common origin, but comparison of the minor folds, faults, and the joints by geographic areas shows that attitudes of these structures are not everywhere duplicated and suggests that the minor structures of the area were not caused by the same forces that caused the major ones. Evidence that the joints on the Paria Plateau change strike with changes of strike of the beds suggests that regional stresses must have caused the minor faults; the movements as shown by slickensides in different areas do not form a consistent pattern.

\section{MINERALIZATION}

Only two mineralized zones are in the House Rock Valley area. Abnormally high radioactivity was noted in a prospect adit near the south boundary of the area in sec. 27, T. 39 N., R. 4 E. (pl. 4). Copper minerals were noted in a prospect at White Pocket in sec. 17, T. 41 N., R. 5 E.

The radioactive material in the prospect adit is localized around a claystone pod about 3 feet long and 1 foot thick in a white coarsegrained sandstone bed in the lower part of the Petrified Forest member of the Chinle formation. No uranium minerals were observed in the rock. A channel sample across the pod contained 0.018 percent uranium, less than 0.05 percent vanadium oxide, and 0.069 percent copper. 
The possibilities of finding economic uranium deposits in the area seem unfavorable. The Shinarump member of the Chinle formation, which is the most important ore-bearing unit in the region, is absent in much of the House Rock Valley area and where the Shinarump is present no mineralization is known. Also, ancient stream channels, which are regionally important guides to ore, are not found in the Shinarump in this area. The lower sands of the Petrified Forest member of the Chinle formation, a potential ore zone, are scarce in the area.

The copper deposit consists of a mineralized zone about 4 feet thick and about 30 feet long in which the copper minerals cement the otherwise friable Navajo sandstone. The zone is vaguely defined on the top by irregular wavy reddish-brown lines of iron oxide. On the bottom, part of the zone is sharply defined by the intersection plane of two sets of cross strata. The ore minerals are concentrated in the lower part of the zone. The mineralized material in detail consists of irregular stringers, lenses, and concretions that tend to follow the cross strata. The mineralized zone is between two northward-striking faults, one about 15 feet west of the zone and the other about 10 feet to the east; the displacement on these faults is from 10 to 20 feet. The faults may have influenced the localization of the mineral deposits, but they show no traces of copper minerals.

On the outcrop the mineralized zone is dull black to red, and contains some malachite and pyrite. Pyrite, tennantite, chalcocite, covellite, malachite, and cuprite were tentatively identified microscopically. The pyrite occurs in a few rounded highly fractured grains. Tennantite, the most abundant mineral, fills pore spaces in the rock and forms the first layer in vugs. Chalcocite forms the second layer of vugs and apparently replaces small patches of the pyrite. Malachite forms the center of vugs and fills fractures in the previously mentioned minerals. Covellite and cuprite occur as irregular patches and as grains throughout the specimen.

A sample of the mineralized zone contained 0.005 percent uranium, less than 0.05 percent vanadium oxide, and 2.01 percent copper.

\section{GROUND WATER}

Ground water of the House Rock Valley area occurs in the bedrock aquifers and in the unconsolidated surficial deposits. Springs issue from the bedrock at several places along the Vermilion Cliffs and at one location, Burro Canyon, on the east side of the Kaibab Plateau. Coyote Spring in Coyote Valley issues from gravel, and several small springs occur at the base of sand dunes on the east side of Coyote Buttes. Several wells were producing water on the Paria Plateau and more were being drilled in 1956. Most of the springs and wells yield only a few gallons per minute. 
The springs at the base of the sand dues are generally small and intermittent. These springs represent, in effect, somewhat delayed runoff of rainwater. Precipitation occurring in sand-dune areas immediately soaks into the sand and percolates to the base of the sand where it runs laterally along the sand-bedrock contact, following the depressions of the bedrock surface and reappearing as a spring at the edge of the dune. Coyote Spring is a permanent spring that issues from unconsolidated gravel deposits about 300 feet east of Coyote Wash. The gravel is largely covered by sand, but it seems to be a southward-trending buried stream channel. If this assumption is true a drainage basin covered by the extensive sand deposits and filled by gravel probably exists in this area. This would serve as an ideal collection basin for the spring water.

All the springs along the Vermilion Cliffs-House Rock Spring, Four Springs, One Mile Spring, and Two Mile Spring-are controlled regionally by the stratigraphy and locally by fracture zones. These springs are near the base of the Navajo sandstone, where the less permeable upper siltstone of the Kayenta formation deflects the ground water laterally. The water is derived from precipitation on the Paria Plateau. The particular location of these springs seems to be controlled by fracture zones associated with minor faults or closely spaced joints. These zones apparently served to concentrate the flow of the ground water. The dip of the beds in this area is generally to the northeast; therefore, gravity flow of the ground water might be expected to be in the direction of dip away from the Vermilion Cliffs. This direction of flow stimulates speculation as to the cause of the springs in a location where the water should be flowing away from the Vermilion Cliffs instead of toward them. Two explanations are advanced: (a) a large reservoir of ground water may be north of the Vermilion Cliffs, the water table being high enough to cause the water to move southward across the updip edge of the Kayenta formation; (b) faulted or jointed zones that strike across the northward flow of the water may act as channels to divert the water from its normal northward flow toward the cliff face. A combination of these conditions probably contributes to the location of the springs.

The intermittent Burro Springs is stratigraphically controlled and is located at the contact between the Hermit and Toroweap formations. The recharge area for this spring is the Kaibab Plateau to the west.

The wells on the Paria Plateau are drilled to the base of the Navajo sandstone, where sufficient water for livestock is found. Not all attempts to find water are successful, although several good wells have been drilled recently.

The possibilities for finding small quantities of water in specific localities in this area seem good. On the Paria Plateau wells drilled 
in the synclines, in fractured zones, or where these occur together would probably produce water. In localities where offset by faults has made a basin at the base of the Navajo sandstone, as in the northeast corner of the area, large quantities of water may be found. The depth to the base of the Navajo sandstone ranges from about 400 feet in the southern part of Paria Plateau to about 1,600 feet in the northern part. Some water under artesian pressure from the Kaibab Plateau may be present in House Rock Valley and Coyote Valley and may be found in the faults on the west side of the northward-trending faults on the east side of the monocline. Water might be artificially impounded in the surficial sand on the Paria Plateau by erecting underground dams on the buried surface of the Navajo sandstone across major drainage systems so as to stop the escape of water flowing along the base of the sand deposits.

\section{LITERATURE CITED}

Babenroth, D. L., and Strahler, A. N., 1945, East Kaibab monocline, Arizona and Utah: Geol. Soc. America Bull., v. 56, p. 107-150.

Baker, A. A., Dane, C. H., and McKnight, E. T., 1931, Preliminary map showing geologic structures of parts of Grand and San Juan Counties, Utah: U.S. Geol. Survey Prelim. Map.

Bessler, Harvey, and Reeside, J. B., Jr., 1921, Oil prospects in Washington County, Utah: U.S. Geol. Survey Bull. 726-C., 20 p.

Colbert, E. H., and Mook, C. C. 1951, The ancestral crocodilian Protosuchus: Am. Mus. Nat. History Bull., v. 97, art. 3, p. 149-182.

Darton, N. H., 1910, A reconnaissance of parts of northwestern New Mexico and northern Arizona: U.S. Geol. Survey Bull. 435, 88 p.

Gilbert, G. K., 1875, Report upon the geology of portions of Nevada, Utah, California, and Arizona, examined in years 1871 and 1872: U.S. Geog. and Geol. Surveys W. 100th Mer. Rept., v. 3, p. 1-187.

Gilluly, James, and Reeside, J. B., Jr., 1926, U.S. Geol. Survey Press Bull. 6064.

Goddard, E. N., chm., and others, 1948, Rock-color chart: Washington, Natl. Research Council [republished by Geol. Soc. America, 1951].

Gregory, H. E., 1915, Igneous origin of the "glacial deposits" on the Navajo Reservation, Arizona and Utah: Am. Jour. Sci., v. 40, 4th ser., p. 97-115.

1917, Geology of the Navajo country-a reconnaissance of parts of Arizona, New Mexico, and Utah: U.S. Geol. Survey Prof. Paper 93, 161p.

1948, Geology and geography of central Kane County, Utah: Geol. Soc. America Bull., v. 59, p. 211-248.

1950, Geology and geography of the Zion Park region, Utah and Arizona : U.S. Geol. Survey Prof. Paper 220, 200 p.

1951, The geology and geography of the Paunsaugunt region, Utah: U.S. Geol. Survey Prof. Paper 226, 116 p.

Gregory, H. E., and Moore, R. C., 1931, The Kaiparowits region, a geographic and geologic reconnaissance of parts of Utah and Arizona : U.S. Geol. Survey Prof. Paper 164, 161 p.

Harshbarger, J. W., Repenning, C. A., and Irwin, J. H., 1957, Stratigraphy of the uppermost Triassic and Jurassic rocks of the Navajo Country: U.S. Geol. Survey Prof. Paper 291, 74 p.

Hunt, C. B., 1956, Cenozoic geology of the Colorado Plateau : U.S. Geol. Survey Prof. Paper 279, 99 p. 
Kelley, V. C., 1955, Regional tectonics of the Colorado Plateau and relationship to the origin and distribution of uranium: New Mexico Univ. Pub. Geology, no. 5, 120 p.

McKee, E. D., 1938, The environment and history of the Toroweap and Kaibab formations of northern Arizona and southern Utah: Carnegie Inst. Washington Pub. 492, $268 \mathrm{p}$.

Miller, V. C., 1950, Pediments and pediment forming processes near House Rock, Arizona : Jour. Geology, v. 58, p. 634-645.

Noble, L. F., 1922, A section of the Paleozoic formations of the Grand Canyon at the Bass trail : U.S. Geol. Survey Prof. Paper 131-B, p. 23-73. 1928, A section of the Kaibab limestone in Kaibab Gulch, Utah:

U.S. Geol. Survey Prof. Paper 150-C, p. 41-60.

Schaeffer, Bobb, and Dunkle, D. H., 1950, A semionotid fish from the Chinle formation, with consideration of its relationships: Am. Mus. Nat. History Novitates, no. 1,457, 29 p.

Simpson, C. T., 1896, Description of four new Triassic Unios from the Staked Plains of Texas : U.S. Nat. Mus. Proc., v. 18, p. 381-385.

Stewart, J. H., 1957, Proposed nomenclature of part of upper Triassic strata in southeastern Utah: Am. Assoc. Petroleum Geologists Bull., v. 41, p. 441-465. Strahler, A. N., 1940, Landslides of the Vermilion and Echo Cliffs, northern Arizona: Jour. Geomorphology, v. 3, p. 285-300.

1948, Geomorphology and structure of the west Kaibab fault zone and Kaibab Plateau, Arizona : Geol. Soc. America Bull., v. 59, p. 513-540.

Ward, L. F., 1901, Geology of the Little Colorado Valley: Am. Jour. Sci., 4th ser., v. 12, p. 401-413. 


\section{MEASURED STRATIGRAPHIC SECTIONS}

The following sections were measured by hand level and staff and by planetable. Most of the data were recorded in the field. Mineral identifications were made with the aid of the petrographic miscroscope and X-ray diffractometer. ${ }^{1}$ Textural relations were observed both megascopically and microscopically. Colors were determined by comparison with a rock-color chart (Goddard and others, 1948).

1. Canyon wall in Burro Canyon in the $E 1 / 2 N E 1 / 4$ sec. $5, T .39 N ., R .9 E$., Coconino County, Ariz.

Permian:

[Measured by J. D. Wells]

Kaibab limestone.

Lower part of Kaibab limestone:

9. Dolomite, yellowish-gray (5Y $7 / 2)$, grading to white $(N 9)$ in upper part ; calcitic, finely crystalline, few sand grains, kaolinite, thick-bedded; bands of chert nodules at about 3-ft intervals, chert sparse lower $30 \mathrm{ft}$; weathers light gray ( $N$ 7), forms cliffs. Fossils common throughout, abundant at base (see McKee, 1938, for fossil list) -...-.-

8. Sandstone, white ( $N 9)$, grading to yellowish-gray ( $5 Y$ $7 / 2$ ) at top; subangular to rounded, rounded frosted grains upper part, well sorted; firmly cemented by dolomite and calcite; some authigenic overgrowth on quartz grains ; massive to faintly cross stratified ; weathers light gray $(N 7)$, forms cliffs

7. Dolomite, yellowish-gray (5Y 8/1) to grayish-yellow (5Y $8 / 4$ ) lower $20 \mathrm{ft}$; very finely crystalline; rounded frosted quartz grains lower $20 \mathrm{ft}$; calcite, kaolinite, thickbedded, calcite geodes abundant in upper part; 15-ft sandstone as unit $8,20 \mathrm{ft}$ above base; weathers light gray ( $N$ 7), forms cliffs

Total lower part of Kaibab limestone

Toroweap formation.

6. Gypsum and anhydrite, white ( $N$ 9) to medium light-gray $(N 6)$, finely crystalline; anhydrite forms irregular beds and stringers; massive to irregular bedded; weathers to steep slope

5. Sandstone, white $(N 9)$ to dark yellowish-orange (10YR 6/6), medium-grained, subrounded to subangular, well-sorted; firmly cemented by calcite and dolomite; massive; weathers to form ledge.

4. Gypsum and anhydrite, white $(N 9)$ to medium-light gray $(N$ 6), finely crystalline; anhydrite forms irregular beds and stringers ; massive to irregular bedded ; weathers to steep slope. Upper half contains 1- to 2-ft beds of sandstone, white

1 Mineral identifications by Richard G. Petersen, U.S. Geological Survey. 
Permian-Continued

Toroweap formation-Continued

Feet

$(N 9)$ and pale-reddish brown $(10 R 5 / 4)$, medium-grained, subangular to subrounded, well-sorted; firmly cemented by gypsum; some authigenic quartz overgrowths; massive; weathers to ledgy slope

3. Dolomitic limestone, yellowish-gray $(5 Y 7 / 2)$ to light olivegray $(5 Y 6 / 1)$, finely crystalline, few sand grains, thickbedded, rare flint nodules; forms subdued cliff ; fossil molds give vuggy appearance (see McKee, 1938, for fossil list) -.-

2. Siltstone, yellowish-gray $(5 Y 7 / 2) ;$ medium grained with coarse rounded frosted quartz grains; firmly cemented by calcite; massive to indistinct bedding; interbedded thin silty limestone with calcite-filled fractures and vugs form prominent ledges

Total Toroweap formation

Hermit shale.

1. Siltstone, moderate reddish-brown $(10 R 4 / 6)$ and grayishorange $(10 Y R 7 / 4)$; coarse grained with coarse rounded frosted quartz sand; angular to subangular, well sorted; chalcedony and feldspar grains; firmly cemented by calcite, kaolinite, and iron oxide; massive to indistinct bedding (incomplete)

2. Road cuts on hairpin curves in the $N \frac{1}{2}$ sec. $3, T .38 N$. . R. $3 E$., Cooonino County, Ariz.

[Measured by J. D. Wells]

Triassic:

Moenkopi formation.

10. Siltstone, pale reddish-brown $(10 R 5 / 4)$, calcareous, thin- to very thin-bedded, micaceous

9. Unconformity, parallel to bedding with minor undulations; upper part of Kaibab limestone vuggy; 2-in zone of fragmental limestone at contact ; fragments coarse- to mediumgrained sand, angular.

Permian :

Kaibab limestone.

Upper part of Kaibab limestone :

8. Dolomite, grayish-orange $(10 Y R 7 / 4)$ with small black dendrites ; finely crystalline, silty, shaly at base, calcareous, thick bedded; weathers to a ledge that has a jagged pitted surface; fossils are Plagioglypta cf. $P$. canna (White), Aviculopecten sp. indet., Pleurophorus sp. indet., myalinid pelecypod indet., Nuculana obesa White, Schizodus sp. indet., Palenucula levatiformis (Walcott) Goniophora sp. indet., Euphemites sp. indet., Knightites (Retispira) sp. indet., and pleurotomarian gastropod indet ${ }^{2}$

Identified by Ellis L. Yochelson, U.S. Geological Survey. 
Permian-Continued

Kaibab limestone-Continued

Upper part of Kaibab limestone-Continued

7b. Siltstone, light-brown $(5 Y R 6 / 4)$, and grayish-red (10 $R 4 / 2$ ), calcareous, thick- to very thin-bedded; weathers to a slope; lower contact gradational_-_----

7a. Dolomite, pale yellowish-brown $(10 Y R 6 / 2)$, finely crystalline, thin- to thick-bedded; at base grades into sandstone, grayish-orange $(10 Y R 7 / 4)$, medium grained; subangular with angular dolomite and chert fragments; poor sorting; weathers to a ledge.

6. Siltstone and interbedded silty limestone, dusky-yellow (5Y 6/4), thin- to thick-bedded; siltstone contain small calcite concretions, and limestone contains flint nodules; weathers to a yellowish-gray (5Y 8/1) slope...-

5. Dolomite, grayish-orange (10YR $7 / 4)$ with grayish-green (5G 5/2) speaks, finely crystalline, calcareous, clayey (illite) ; few quartz and microcline grains; thick bedded, few chert nodules; weathers to a jagged pitted surface forms prominent ledge throughout area

21

4. Siltstone, grayish-yellow (5Y 8/4), pale reddish-grown $(10 R 5 / 4)$, and moderate reddish-brown $(10 R 4 / 6)$; clayey, very thin to thick bedded; lower surface of red beds wavy; upper part has silty limestone, yellowish-gray (5Y 8/1); $10 \mathrm{ft}$ from top is chalcedonic quartz bed, white $\left(\begin{array}{ll}N & 9\end{array}\right)$ and moderate orange-pink $(10 R 7 / 4)$ which forms resistant ledge; unit weathers to a ledgy slope.

3. Dolomite, mudstone, chalcedony, and sandstone in a sequence of beds. Dolomite, light olive-gray (5Y 6/1), very finely crystalline with large secondary calcite crystals; forms upper $3 \mathrm{ft}$ of unit; weathers olive gray $(5 Y 4 / 1)$, with jagged pitted surface and forms prominent ledge. Middle part chelcedony ; white $(N 9)$, with yellowish-gray (5Y 8/1) stringers of sandstone; very finely crystalline, porous, some flint nodules. Lower part sandstone, yellowish-gray (5Y 8/1), very fine grained, subangular, well-sorted, firmly cemented by calcite, laminated. Mudstone; pale-olive (10Y 6/2) with small grayish-green $(5 G 5 / 2)$ patches; silty, kaolinite, illite (?), massive; occurs as beds a few feet thick throughout unit. Unit weathers to ledgy slope--

2. Limestone, sandstone, and chert in an intimate mixture of beds, stringers and patches. Limestone, very pale orange $(10 Y R \quad 8 / 2)$; finely crystalline with sand grains increasing in abundance near sandstone contact. Sandstone, yellowish-gray ( $5 Y 7 / 2)$, fine-grained, subangular to subrounded, well-sorted, authigenic quartz overgrowths, feldspar grains, heavy minerals concentrated near flint contact ; firmly cemented by quartz overgrowth, chalcedony, and calcite. Chalcedony, white $(N 9)$ and medium-gray ( $N 5$ ), coarse to fine-grained, massive, spherulitic, and banded; some quartz crystals as vug fillings, few quartz grains; unit weathers to a ledge 


\section{STRATIGRAPHY AND STRUCTURE, HOUSE ROCK VALLEY, ARIZ. 145}

\section{Permian-Continued}

Kaibab limestone-Continued

Upper part of Kaibab limestone-Continued

1. Chert, white $(N 9)$, patches of fine-grained sandstone, some iron oxide, highly fractured, vuggy, vugs contain large calcite crystals, weathers to gravelly slope_-----Total upper part of Kaibab limestone.....-.--

Contact with lower part of Kaibab limestone.

3. Wash west of Coyote Spring in the $\$ 1 / 2$ sec. 14, T. 41 N., R. $9 \mathrm{E}$., Coconino County, Ariz.

[Measured by J. D. Wells]

Triassic :

Chinle-Moenkopi contact.

Moenkopi formation.

6. Siltstone, pale reddish-brown $(10 R 5 / 4)$ with layers of light greenish-gray (5G 8/1); chlorite, kaolinite, calcareous, clayey, thin to very thin bedded; weathers to a rounded platy slope

5. Siltstone, light greenish-gray $(5 G Y 8 / 1)$ with 2 -foot pale reddish-brown $(10 R 5 / 4)$ bed 4 feet from base; clayey, calcareous, thin- to very thin-bedred; weathers to a slope

4. Siltstone, interbedded (1) pale reddish-brown $(10 R 5 / 4)$, thin to very thin bedded, predominantly in lower part; (2) grayish-red $(10 R 4 / 2)$, thick to thin bedded, predominantly in middle part; and (3) moderate reddish-brown (10R 4/6), thin bedded to very thin bedded, predominantly in lower part; few grayish-orange $(10 R 7 / 4)$, grayish yellow-green $(5 G Y 7 / 2)$ and yellowish-gray $(5 Y 7 / 2)$ beds; clayey, sandy, calcareous, some biotite and muscovite, ripple marks ; weathers to rounded slopes and subdued ledges

3. Siltstone, pale reddish-brown $(10 R 5 / 4)$ with moderate orangepink $(10 R 7 / 4)$ in 1 - to 2 -ft beds in lower part; upper part gypsiferous ; calcareous ; clayey, sandy, thin to very thin bedded, ripple marked; weathers to rounded platy slope--.---

2. Siltstone, grayish-orange $(10 Y R 7 / 4)$ and moderate orangepink (10R 7/4), alternating clayey and sandy beds; some rounded frosted grains and angular chert fragments ; calcareous, thin to thick bedded, even to irregular bedded; weathers to a ledgy slope

Permian :

1. Unconformity, sharp with small irregularities.

Kaibab limestone.

4. Composite on hillside, stock pond in the NW1/4NW1/4 sec. 2, T. 40 N., R. 3 E., Coconino County, Ariz.

[Measured by J. D. Wells]

Triassic :

Chinle formation.

Petrified Forest member (incomplete) :

3. Sandstone, yellowish-gray ( $5 Y$ 8/1), fine-grained, subrounded, well-sorted, silty, clayey (kaolinite), very calcareous, gypsiferous, plagioclase grains, firmly cemented, lenticular, massive; weathers to rounded powdery slope (incomplete) 


\section{Triassic-Continued}

Chinle formation-Continued

Shinarump member :

2. Sandstone, moderate yellowish-brown (10YR 5/4), coarsegrained, in places conglomeratic, subrounded to rounded, poorly sorted, pebbles are quartz and quartzite; calcareous, poorly cemented, massive to thin bedded; weathers light gray $(N 7)$ rounded pebble-covered slope.

1. Sandstone, yellowish-gray ( $5 Y$ 8/1), medium-grained, subrounded, well-sorted, calcareous, firmly cemented, lenticular, thick- to thin-bedded partly cross-stratified; weathers to a light gray ( $N 7$ ), resistant ledge

Total Shinarump member (average)

Moenkopi-Chinle contact poorly exposed.

5. Ridge east of northern Coyote Wash in the $S W 1 / 4 S W 1 / 4$ sec. $\$ 6, T .42 N$., R. $3 E$., Coconino County, Ariz.

Triassic:

[Measured by J. D. Wells]

Chinle formation.

Petrified Forest-Shinarump contact; mostly concealed.

Shinarump member :

3. Sandstone, white ( $N 9)$, fine- to coarse-grained, rounded to subangular poorly sorted; conglomeratic with quartzite and claystone pebbles ; chalcedony microcline, and quartzite grains; quarty overgrowth; firmly cemented by quatz, gypsum, and clay (kaolinite); massive to thick bedded; weathers to a cliff.

2. Siltstone, very light gray ( $N 8)$, with 2 -ft yellowish-gray $(5 Y 8 / 1)$ bed in middle part; fine to coarse grained, subangular to rounded, fair sorted, sandy; chalcedony, microcline, and muscovite grains; firmly cemented by quartz overgrowths, clay (kaolinite), and gypsum; thin bedded

1. Sandstone (same as unit 3 )

Total Shinarump member

Moenkopi formation.

1. Siltstone, moderate reddish-brown $(10 R 4 / 6)$ bleached to light greenish-gray (5GY 8/1) within few inches of contact with Shinarump member of the Chinle formation ; contact sharp and regular (incomplete)

6. Wash northeast of Coyote Springs in the N1/2 sec. 13, T. 41 N., R. B E., Conconino County, Ariz.

[Measured by J. D. Wells]

Jurassic and Jurassic(?) :

Navajo sandstone (incomplete).

13. Sandstone, moderate reddish-orange $(10 R 6 / 6)$, fine-grained subrounded to rounded, frosted, well-sorted; chalcedony and microcline grains; weakly cemented by iron oxide and clay (kaolinite) ; inconspicuous large-scale tangential crossstratification; weathers to a cliff (incomplete) 
Jurassic ( ?) :

Kayenta formation.

12. Sandstone, pale reddish-brown $(10 R 5 / 4)$ with 20 - to 30 -ft beds of moderate orange-pink $(10 R 7 / 4)$, and 1-ft beds of pinkish-gray (5YR 8/1) in middle part; fine grained, subangular to rounded, well sorted, few frosted grains, silty; chalcedony and microcline grains; firmly cemented by kaolinite, dolomite, and iron oxide; massive to thin bedded in part cross stratified on a moderate to small scale: interbedded with siltstone, pale reddish-brown (10R 5/), medium-grained, angular to subrounded, well-sorted, clayey, thin to very thin bedded. Near top are beds of moderate orange-pink $(10 R 7 / 4)$, thin-bedded, calcareous, weathers light-brown $(5 Y R 5 / 6)$ : formation weathers to 20 - to 30 -ft ledges and slopes in which the sandstone forms the ledges and the siltstone the slopes_-

Total Kayenta formation.

Triassic(?)

Moenave formation.

Springdale sandstone member :

11. Sandstone, moderate reddish-orange (10R 6/6) grading downward into moderate-red ( $5 R 5 / 4)$ with crescentshaped areas of dark yellowish-orange $(10 Y R$ 6/6) crossing the bedding; fine grained, well sorted, subangular to rounded, silty ; chalcedony, feldspar, muscovite, and biotite grains; firmly cemented by carbonate (dolomite and calcite), clay (kaolinite), and iron oxide; thick to thin bedded with some cross-stratification; upper part contains lenticular cross-stratified beds of conglomerate with angular sandstone, siltstone, and limestone pebbles cemented by calcite; unit forms cliff

Total Springdale sandstone member-

Dinosaur Canyon sandstone member:

10. Siltstone, upper part moderate reddish-orange (10R 6/6) with dark yellowish-orange $(10 Y R \quad 6 / 6)$; coarse grained, angular to subangular, well sorted, sandy; firmly cemented by calcite and iron oxide; thick to very thin bedded, ripple marks common, cross stratified in part. Lower part moderate reddish-brown (10R 4/6) with yellowish-gray (5Y 7/2) spots and thin beds; fine grained, clayey (montmorillonite), plagioclase grains, calcareous, thin to very thin bedded; in lower part thin claystone beds, dark reddish-brown (10R 3/4); upper part weathers to a cliff, lower part to a ledgy slope

Total Dinosaur Canyon sandstone member 
Triassic:

Chinle formation.

Owl Rock member :

9b. Mudstone, dark reddish-brown (10R 3/4) with few paleolive $(10 Y 6 / 2)$ spots; montmorillonite slightly bentonitic, silty, massive; upper $20 \mathrm{ft}$ contains pale-red ( $5 R$ 6/2) finely crystalline nodular limestone; weathers to a rounded slope with a granular appearing surface

Total Owl Rock member

Petrified Forest member :

9a. Siltstone, grayish-red $(5 R 4 / 2)$ with thin pale grayishyellow $(10 Y 8 / 2)$ beds; bentonitic, clayey (montmorillonite and kaolinite), calcareous; veinlets of gypsum occur $50 \mathrm{ft}$ from top; massive to thin bedded. Basal $20 \mathrm{ft}$ and thin beds in upper part are sandstone, lightgray $(N \mathrm{~N})$, mottled and stringered with grayish-red $(10 R 4 / 2)$; fine to coarse grained, angular to subangular, poorly sorted, bentonitic, silty and clayey (montmorillonite and kaolinite), calcareous, thick bedded to cross stratified; some of the upper sandstone beds are conglomeratic with angular siltstone and limestone, and rounded quartzite pebbles. Unit weathers to a ledgy rounded frothy-appearing slope

8. Mudstone, mottled light-gray $(N 7)$ and medium-gray $(N$ 5) with beds and spots of grayish-red $(5 R 4 / 2)$ and spots of pale-olive (10Y 6/2); bentonitic, silty, montmorillonite, massive; calcite concretion zone near middle; weathers to a rounded frothy appearing slope

7. Mudstone, variegated medium light-gray $(N 6)$, grayishred $(10 R 4 / 2)$, pale-red $(5 R 6 / 2)$, and moderate yellowish-brown (10RY 5/4); bentonitic, silty, montmorillonite, kaolinite, thin to thick bedded. Near middle of unit sandstone, light-gray ( $N 7$ ), with grayish-red (10R 4/3) spots; fine grained; biotite and feldspar grains; thin bedded. Unit weathers to rounded rilled frothy-appearing slope

6. Sandstone, very light gray $(N 8)$ with dark yellowishorange $(10 Y R 6 / 6)$ lenses in upper part and thin beds of medium dark-gray ( $N$ 4) near upper contact; coarse to fine grained, angular to subrounded, poorly sorted; microcline, plagioclase, chalcedony, and mica grains, silty, clayey (montmorillonite, and kaolinite) ; firmly cemented to friable; locally contains angular quartz and claystone pebbles; dark yellowish-orange lenses contains woody material and gypsum. Middle part is siltstone, grayish-red $(5 R 4 / 2)$ and olive-brown (5Y $4 / 4)$, coarse grained; contains agate and calcareous concretions ; massive. Unit weathers to a steep pound slope

5. Siltstone, light brownish-gray (5YR 6/1), coarse-grained, angular to subrounded, poorly sorted, bentonitic, clayey, weakly cemented, massive; upper $10 \mathrm{ft}$. is mudstone, grayish-red (10R 4/2), silty; unit weathers to rounded frothy-appearing slope 


\section{Triassic-Continued}

Chinle formation-Continued

Petrified Forest member-Continued

Feet

4. Sandstone, very light gray ( $N$ 8) motted with dark reddish-brown $(10 R 3 / 4)$ in upper part, in places has halo of grayish-red (10R 4/2); fine grained, subangular to subrounded, well sorted, silty and clayey; upper part massive, lower part thin bedded; gradational interfingered lower contact; weathers to subdued cliff--

3. Siltstone, mottled grayish-red $(10 R 4 / 2)$ pale greenishyellow $(10 Y 8 / 2)$ and dusky-yellow (5Y 6/4); finegrained clayey, calcareous, massive; lower part contains hematite concretions; weathers to a rounded slope-..-

Total Petrified Forest member-_______-__-_

Total Chinle formation

Moenkopi formation (incomplete).

2. Siltstone, moderate-brown $(5 Y R \quad 4 / 4)$, and grayish-red $(10 R 4 / 2)$, with thin beds of pale-olive $(10 Y 6 / 2)$; mediumgrained, clayey calcareous, thin- to very thin bedded, ripplemarked; weathers to ledgy rounded slope

1. Siltstone, pale greenish-yellow $(10 Y 8 / 2)$ and grayish-red (10R 4/2), medium-grained, clayey, gypsiferous, thin- to very thin bedded; weathers to a rounded slope

Moenkopi formation (incomplete)

7. Vermilion Cliffs at Four Springs in the $S W 1 / 4$ sec. 11, T. 39 N., R. 3 E., Coconino County, Ariz.

[Measured by Richard G. Petersen and J. D. Wells]

Jurassic and Jurassic(?)

Navajo sandstone (incomplete).

19. Sandstone, moderate reddish-orange $(10 R 6 / 6)$, verg fine to medium-grained, larger grains frosted, subangular to wellrounded, poorly sorted; chalcedony and feldspar grains; poorly cemented by iron oxide; large-scale tangential cross stratification; weathers to prominent nearly vertical cliff-Navajo sandstone (incomplete)

Jurassic ( ?)

Kayenta formation.

18. Sandstone (same as unit 14) 60 percent of unit, siltstone (same as unit 13) 20 percent of unit, and siltstone (same as unit 12) 20 percent of unit, in alternating sequence, upper part predominantly sandstone, sandstone forms ledges and siltstone forms slopes

17. Sandstone (same as unit 14)

16. Siltstone (same as unit 13)

15. Siltstone (same as unit 12)

14. Sandstone, moderate reddish-orange $(10 R 6 / 6)$, very fine to medium-grained, angular to subrounded, fairly sorted, silty; chalcedony and feldspar grains; weakly cemented by calcite, dolomite, and iron oxide; thick bedded, upper part cross stratified on medium scale; weathers to a ledgy slope.-.- 
Jurassic(?)-Continued

Kayenta formation-Continued

13. Siltstone, moderate reddish-brown $(10 R 4 / 6)$ with thin beds of yellowish-gray ( $5 Y 8 / 1$ ), fine- to coarse-grained, angular to subangular, fair-sorted, sandy, feldspar grains; weakly cemented by calcite, dolomite, and iron oxide; thin bedded to massive, minor small-scale cross-stratification; weathers to form a ledge.

12. Siltstone, moderate reddish-brown $(10 R 4 / 6)$, clayey (montmorillonite) very thin bedded; weathers to a gentle slope. Near base are beds of sandstone, moderate reddish-orange $(10 R 6 / 3)$ and yellowish-gray $(5 Y 8 / 1)$, very fine to medium-grained, subangular to subrounded, fair-sorted; chalcedony and feldspar grains; firmly cemented by dolomite in yellowish-gray sandstone and by iron oxide in the red sandstone; thick bedded to cross stratified; weathers to a ledge

Total Kayenta formation

Triassic(?) :

Moenave formation.

Springdale sandstone member :

11. Sandstone, pale reddish-brown $(10 R 5 / 4)$ and moderate reddish-brown $(10 R 4 / 6)$, very fine to medium-grained, angular to subrounded, silty; feldspar, biotite, and muscovite grains; weakly cemented by iron oxide and small spheres of kaolinite; massive to cross stratified on a medium scale; lenses of conglomerate in upper part containing angular siltstone and limestone fragments ; weathers to a cliff

10. Claystone, moderate reddish-brown $(10 R 5 / 4)$ with spots of pale-olive (10Y 6/2), silty, montmorillonite(?), thinto very thin bedded; weathers to a gentle slope.

9. Sandstone (similar to unit 11) with lenses of conglomerate containing angular siltstone and limestone fragments near base of unit

8. Sandstone, moderate reddish-orange $(10 R$ 6/6) with irregular patches of yellowish-gray (5Y 7/2), angular to subrounded, fine-grained, fair-sorted, silty ; firmly cemented by dolomite and iron oxide; thin to thick bedded. Intertongued with the sandstone are lenses of siltstone, pale reddish-brown $(10 R 5 / 4)$ and pale greenish-yellow (10Y 8/2), sandy and clayey, very thin bedded. Sandstone weathers to cliff, siltstone to slopes_.

Total Springdale sandstone member.

Dinosaur Canyon sandstone member :

7. Siltstone, moderate reddish-brown $(10 R 4 / 6)$ with very pale green ( $10 G 8 / 2$ ) spots, medium- to coarse-grained, angular to subrounded, sandy; weakly cemented by calcite, iron oxide, and montmorillonite(?); thick to very thin bedded; weathers to a ledgy slope; fish remains near upper contact 
STRATIGRAPHY AND STRUCTURE, HOUSE ROCK VALLEY, ARIZ. 151

Triassic(?)-Continued

Moenave formation-Continued

Dinosaur Canyon sandstone member-Continued

6. Mudstone, variegated dark reddish-brown $(10 R 3 / 4)$ and light greenish-gray (5G 8/1), silty, montmorillonite, minor kaolinite, calcite, dolomite, mica, iron oxide, very thin bedded; weathers to a rounded slope; contains poorly preserved fresh-water ostracodes ${ }^{3}$ from top

5. Siltstone, dusky-yellow (5Y 6/4) with very thin beds of moderate reddish-brown $(10 R 4 / 6)$, medium- to coarsegrained, angular to subangular, well-sorted, calcareous, mica and feldspar grains; thick bedded with some poorly developed cross-stratification weathers to ledgy slope

4. Siltstone, moderate reddish-brown $(10 R 4 / 6)$ with very pale green (10G 8/2) spots and thin beds, fine- to coarse-grained, sandy, clayey ; weakly cemented by iron oxide and calcite; sandy part thin to thick bedded, clayey part very thin bedded; weathers to a gentle slope

Total Dinosaur Canyon sandstone member

Triassic:

Chinle formation.

Owl Rock member:

5. Limestone, mottled pale-red $(5 R 6 / 2)$ and light brownishgray (5YR 6/1) ; finely crystalline and coarsely crystalline with small vug and fracture fillings of calcite; nodular; weathers light olive-gray (5Y 6/1), forms ledge

4. Mudstone, dark reddish-brown $(10 R 3 / 4)$ with thin beds and spots of pale-olive $(10 Y 6 / 2)$; silty, montmorillonite, slightly bentonitic, massive; weathers to a rounded slope with a granular-appearing surface.

3. Limestone, mottled pale-red $(5 R 6 / 2)$ and light greenishgray (5G 8/1) ; finely crystalline with small vugs and fractures filled with clear calcite; massive to nodular; irregular beds of flint; weathers light olive-gray (5Y 6/1) ledge

2. Mudstone (same as unit 4)

Total Owl Rock member

Petrified Forest member (incomplete).

1. Sandstone, variegated pale-red $(10 R$ 6/2) and light greenish-gray (5GY 8/1), fine-grained, angular to subrounded, poorly sorted, silty clayey (montmorillonite); feldspar, biotite, and muscovitegrains; bentonitic; weakly cemented by calcite; thin beds of angular limestone conglomerate; weathers to a steep rounded slope (incomplete)

- Identification by I. G. Sohn, U.S. Geological Suryey. 
8. Vermition Cliffs nnear House Rock Ranch, in the NE sec. 30, T. 39 N., R. 4 E., Conconino County, Ariz.

Jurassic and Jurassic (?) :

[Measured by J. D. Wells]

Navajo sandstone (incomplete).

10. Sandstone, light-brown $(5 Y R 6 / 4)$, fine- to medium-grained, subangular to rounded, frosted, well-sorted, silty, ferruginous friable, large- and medium-scale tangential crossstratification; weathers to nearly vertical cliff (incomplete) about

Jurassic ( ?) :

Kayenta formation.

9. Sandstone, moderate reddish-orange $(10 R 6 / 6)$ and white (N 9) with siltstone, moderate reddish-brown (10R 6/6). Sandstone, moderate reddish-orange $(10 R \mathrm{6} / 6)$, fine- to medium-grained, subangular to rounded, well-sorted, silty; chalcedony and feldspar grains; ferruginous, kaolinite in small spheres, weakly cemented; thin to thick bedded, in part cross stratified on a small scale; some ripple marks. Sandstone, white $(N 9)$, fine-grained, angular to subangular, well-sorted; chalcedony, feldspar, biotite, and muscovite grains; silty; firmly cemented by carbonate; thin bedded. Siltstone, moderate reddish-brown with thin beds of light greenish-gray ( $5 G Y 8 / 1$ ) ; coarse, angular to subangular, well-sorted, sandy; chalcedony and feldspar grains; weakly cemented by dolomite, calcite, montmorillonite, and iron oxide; thin bedded with small-scale cross-stratification in places. The unit forms ledgy slope; sandstone forms ledges and the siltstone forms slopes 10 to $40 \mathrm{ft}$ thick; the white sandstone forms prominent 1-ft-thick ledges in the middle part of the formation Total Kayenta formation

Triassic (?) :

Moenave formation.

Springdale sandstone member :

7. Sandstone, pale reddish-brown $(10 R 5 / 4)$ with lenticular beds of moderate orange-pink $(10 R 7 / 4)$; fine grained, well to fair sorted, subangular to subrounded, silty; chalcedony, feldspar, biotite, and muscovite grains; weakly cemented by iron oxide, calcite, and small spheres of kaolinite; very thick bedded; contains stringers and lenses of conglomerate with angular sandstone, siltstone, and mudstone pebbles in a modedate reddish-brown $(10 R 4 / 6)$ siltstone matrix most common near base. Member forms a prominent cliff, basal contact gradational

Total Springdale sandstone member.

Dinosaur Canyon sandstone member :

6a. Siltstone, moderate reddish-brown $(10 R 4 / 6)$ to pale reddish-brown $(10 R 5 / 4)$ with spots and stringers of light greenish-gray (5G 8/1) ; medium grained, subangular to subrounded, well sorted; firmly cemented by calcite and iron oxide; thin bedded; interbedded 
STRATIGRAPHY AND STRUCTURE, HOUSE ROCK VALLEY, ARIZ. 153

Triassic(?)-Continued

Moenave formation-Continued

Dinosaur Canyon sandstone member-Continued

with sandstone; moderate reddish-brown (10R 4/6)

with light greenish-gray ( $5 G 8 / 1$ ) spots and stringers;

fine grained, well sorted, silty ; chalcedony, and feldspar

grains; cemented by calcite and iron oxide; thick bedded with some thin bedded, some cross-stratification on a small scale. Unit forms a slope with subdued ledges of sandstone.

6. Siltstone, variegated moderate yellowish-brown (10YR $5 / 4)$, pale yellowish-brown (10YR 6/2), grayish-red $(10 R 4 / 2)$, and pale-olive (10Y 6/2) ; medium grained, clayey (montmorillonite), calcareous, thin to very thin bedded, weathers to slope; contains ostracodes and a conchostracan 4

5. Sandstone and siltstone as described in unit $6 a$ but with sandstone comprising more of the unit

Triassic : Total Dinosaur Canyon sandstone member.--.-Total Moenave formation

Chinle formation.

Petrified Forest member :

4a. Mudstone with sandstone and conglomeratic sandstone. Mudstone (90 percent) dark reddish-brown (10R 3/4), interbedded with pale yellowish-greem $(10 G Y 7 / 2)$ in lower quarter of unit, and local beds of brownish-gray (5YR 4/1); silty, calcareous, bentonitic, massive; spherulitic geodes of calcite with barite crystals in the center in the lower quarter; weathers to rounded rilled frothy-appearing slope. Sandstone (9 percent), palebrown $(5 Y R 5 / 2)$, pale-red $(5 R 6 / 2)$, and grayish yellow-green $(5 G Y 7 / 2) ;$ medium-grained silt to medium-grained sand, angular to subangular, fair sorted ; chalcedony, feldspar, biotite, and muscovite; firmly cemented by montmorillonite and calcite; smallscale cross-stratification, weathers to steep, rounded slopes. Conglomeratic sandstone (1 percent), pale yellowish-green (10YR $7 / 2)$; coarse grained with variable sized pebbles; sand, angular to subangular, wellsorted; chalcedony, feldspar, biotite, and muscovite; pebbles rounded to angular, poor sorting, limestone; firmly cemented by calcite; lenticular, small-scale cross-stratification; forms thin ledges; "Unio" graciliratus Simpson ${ }^{5}$ and bone fragments in upper part.-

4. Mudstone, grayish-red $(10 R 4 / 2)$ with pale greenishyellow spots ( $10 Y 8 / 2)$; silty, bentonitic, massive; weathers to rounded slope

- Identified by I. G. Sohn, U.S. Geological Survey.

Identified by John B. Reeside, Jr., U.S. Geological Survey. 
Triassic-Continued

Chinle formation-Continued

Petrified Forest member-Continued

3. Mudstone, sandstone, and conglomeratic sandstone, mostly pale reddish-brown (10R 5/4); lenticular with gradational boundaries. Mudstone, dark reddishbrown $(10 R 3 / 4)$ with pale-olive spots $(10 Y$ 6/2); bentonitic, silty, massive, about $13 \mathrm{ft}$ thick. Underlain by sandstone, pale reddish-brown $(10 R 5 / 4)$, fine grained, angular to subrounded, well-sorted; chalcedony and feldspart grains; betonitic, clayey, poorly cemented, cross stratified on small scale; interlensed with siltstone; pale red $(10 R 6 / 2)$ with pale-olive (10Y 10/4) spots and stringers; about $20 \mathrm{ft}$ thick. Underlain by conglomeratic sandstone, pale-brown $(5 Y R 5 / 2)$ and light brownish-gray (6YR 5/1) ; coarse grained with variable sized pebbles; rounded to angular, poorly sorted; limestone and clay pebbles with chalcedony and feldspar grains ; well cemented by calcite ; poorly developed small-scale cross-stratification; lenticular about 5 ft thick. Underlain by mudstone; grayish-red (10R 4/2) with pale-olive (10Y 10/4) spots and stringers; bentonitics, silty, motmorillonite, slightly calcareous, massive; about $15 \mathrm{ft}$ thick. Mudstone weathers to rounded frothy-appearing slope, sandstone forms steep rounded slope, and conglomeratic sandstone forms ledges

2. Mudstone, grayish red-purple $(5 R P 4 / 2)$ with small palepink $(5 R P$ 8/2) spots interbedded with grayish-purple (5P 4/2) with small spots of grayish yellow-green $(5 G Y 7 / 2)$; bentonitic, silty, montmorillonite, slightly calcareous, massive, irregular calcite nodules; weathers grayish red purple $(5 R P 4 / 2)$ to light gray $(N 7)$; weathers to rounded frothy-appearing slopes (incomplete)

Freet

Petrified Forest member (incomplete) -.--_---- $\mathbf{4 7 2}$

9. Cliff face at White Pocket in the NW1/4NW1/4 sec. 17, T. 41 N., R. 5 W., Coconino County, Ariz.

Jurassic :

[Measured by J. D. Wells]

Carmel formation intertongued with Navajo sandstone.

Upper contact concealed.

9. Sandstone, mottled white ( $N 9)$ and grayish-brown (5YR 3/2), medium-grained, rounded, frosted, well-sorted; firmly cemented by calcite ; thin-bedded to small-scale cross-stratification

8. Sandstone, white ( $N$ 9) with medium dark-gray $(N$ 4) spots and pale reddish-brown (10Y 5/4) stringers, medium-grained, subrounded to rounded, frosted, well-sorted, friable, mediumscale cross-stratification

7. Sandstone (same as unit 9)

6. Sandstone (same as unit 8) 
STRATIGRAPHY AND STRUCTURE, HOUSE ROCK VALLEY, ARIZ. 155

Jurassic-Continued

Carmel formation intertongued with Navajo sandstone-Continued

Feet

5. Limestone, pale-red $(5 R 6 / 2)$ to pale reddish-brown $(5 R 10 / 4)$ with very light gray $(N 8)$ spots, finely crystalline; lower part is very silty to sandy with orthoclase, illite, and kaolinite; upper part has subconchoidal fracture; unit weathers to slope.

4. Sandstone (same as unit 8)

3. Sandstone, grayish-red $(10 R 4 / 2)$ with irregular patches of very dusky red $(10 R 2 / 2)$; fine grained, rounded to well rounded well-sorted; firmly cemented with calcite and iron oxide; thin bedded and planar cross stratified on small scale; lenticular ; weathers to prominent ledge

2. Siltstone, pale reddish-brown (5YR 10/4) with layers of white ( $N$ 9) flecks; coarse grained, angular to subrounded, well sorted, few rounded frosted quartz grains; layers of white flecks are clay ; firmly cemented by iron oxide

Carmel formation (incomplete) -

Jurassic and Jurassic(?) :

Navajo sandstone.

1. Sandstone, pinkish-gray ( $5 Y R 8 / 1$ ), fine-grained sub-angular to rounded, well-sorted, frosted, friable, large-scale tangential cross-stratification; weathers to a cliff (incomplete) -...-.-.- 



\section{INDEX}

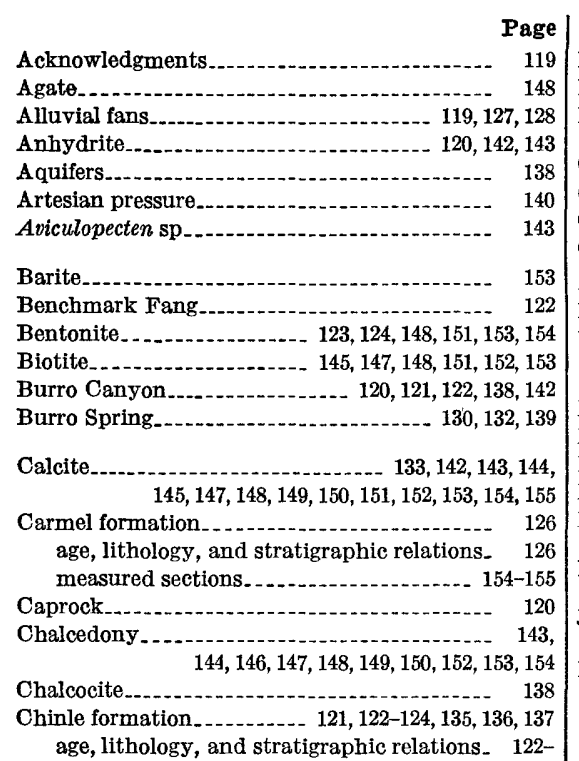
age, lithology, and stratigraphic relations. $\begin{array}{r}122- \\ 124\end{array}$

fossil content.

123,153

measured sections 145-146,

Owl Rock member $148-149,151,133-134$

Petrified Forest member. $123-124,148,151$

$123,127,133,138,145,148-149,151,153$

Shinarump member 122-123, $132,133,134,137,138,146$

Chlorite

Circle Cliffs area, Utah.......................... 129

Circle Cliffs upwarp............................ 129

Climate

Coconino sandstone. .....................120, 121

Colorado Plateau_._._............. 119, 128, 129

Copper minerals............................... 137, 138

Covellite_._. _................. 138

Coyote Buttes...-..................119, 134, 135, 138

Coyote Spring.-122, 124, 125, 126, 130, 133, 138, 139, 146 Coyote Valley ................132, 133, 134, 135, 138, 140 Coyote Wash_-....-.-_-_121, 122, 124, 128, 134, 139, 146 Cuprite.

Dams

Darwinula

Dockum group ............................ 123

Drag folds.

$129,132,133,134,136$

East Kaibab monocline ..... 119, 121, 128, 129-132, 136 Echo Cliffs monocline. Euphemites sp.
Faults_. $127,128,129,130,131,132-136,137,138,139,140$

Fieldwork.................................. 119, 142

Four Springs._..................... 124, 125, 139, 149

Glen Canyon group

Goniophora sp................................ 143

Grabens

Gypsum........ 120, 121, 122, 142, 143, 145, 146, 148, 149

Hematite ...._.

Hermit shale _...................... 120, 121, 139

age, lithology, and stratigraphic relations. $\quad 120$ measured sections........................- 143 Horsts........................................ 133, 136, 137 House Rock Ranch ........................... 152

House Rock Spring

House Rock Valley, location................. 118, 119 House Rock Wash.......... 119, 121, 122, 124, 127, 128 Illite

Joints. . . .

Kaibab limestone ............... 119, 121, 122, 128, 130 age, lithology, and stratigraphic relations........................ 119, 120, 121 alpha member............................ 121

fossil content. . ...................... 121, 142, 143 lower part.......................... 121, 142, 145

measured sections. . . . . .

upper part. ........................ 121, 143-145

Kaibab Plateau .... 119, 120, 128, 129, 137, 138, 139, 140 Kaolinite... 142, 143, 144, 145, 146, 147, 148, 151, 152, 155 Kayenta formation . . . $125,126,127,133,134,135,136,139$ age, lithology, and stratigraphic relations..-- 125 measured sections............... 147, 149-150, 152 Knightites (Retispira) sp................. 143

Landslide deposits..................... 119, 120, 127 Lees Ferry _._._._.

Malachite_............. 138

Moenave formation ................... 124-125, 136 age, lithology, and stratigraphic relations. . . . .

Dinosaur Canyon sandstone member..... 124, $127,147,150-153$ fossil content ...... 124,150,151,153 measured sections . ................... 147, 150-153 Springdale sandstone member........... 124, $127,147,150,152$ Moenkopi formation....................... 121 $122,123,132,133,135,136,137$ age, lithology, and stratigraphic relations.............................. 122 measured sections............... 143, 145, 146, 149 


\begin{tabular}{|c|c|}
\hline $\begin{array}{r}\text { Page. } \\
\text { Montmorillonite_........ 147, 148, 150,151, 152, 153, } 154\end{array}$ & $\begin{array}{r}\text { Page } \\
\text { Sand dunes. }\end{array}$ \\
\hline Monument Valley & Schizodus sp_.. \\
\hline$\ldots 145,146,147,152,153$ & 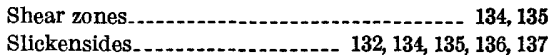 \\
\hline Navajo Country & Step faults. \\
\hline Navajo Indian Reservation. & Structural features, origin \\
\hline $\begin{array}{r}\text { Navajo sandstone } \\
120,125-127,133,134,135,136,138,139,140\end{array}$ & Supai formation, stratigraphic relations_....... \\
\hline $\begin{array}{l}\text { age, lithology, and stratigraphic rela- } \\
\text { tions. }\end{array}$ & $\begin{array}{l}\text { Tennanite } \\
\text { Thrust faults. }\end{array}$ \\
\hline measured sections.......... $146,149,152,154-155$ & - \\
\hline $\begin{array}{l}\text { Vuculana obesa } \\
\text { ne Mile Spring. }\end{array}$ & $\begin{array}{r}\text { Toroweap formation } \\
\text { age, lithology, and stratigraphic relations }-{ }_{-1} \\
120-\end{array}$ \\
\hline alenucula levatiformis.-. & $\begin{array}{l}\text { fossil content } \\
\text { measured sections. } \ldots \ldots \ldots \ldots\end{array}$ \\
\hline aria Plateau............... 119 & Two Mile Spring.-.- \\
\hline $125,128,129,136,137,138,139,140$ & Unio graciliratus $\ldots \ldots \ldots \ldots$ \\
\hline $\begin{array}{ll}\text { Paunsaugunt region. } & 119 \\
\text { Pediment }\end{array}$ & Uranium-bearing sandstone._......... $123,137,138$ \\
\hline Petrified wood. & 119,136 \\
\hline Plagioglyptacanna. & Vermilion Cliffs... \\
\hline Pleus & $124,125,127,133,136,138,139,149,152$ \\
\hline Precipitation. & \\
\hline Pyrite & $\begin{array}{l}\text { Wells, water } \\
\quad \text { yield }\end{array}$ \\
\hline 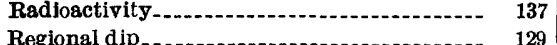 & Whito Pocket_. \\
\hline 9 &, 125 \\
\hline
\end{tabular}



